\title{
Sargassum blooms in the Caribbean alter the trophic structure of the sea urchin Diadema antillarum
}

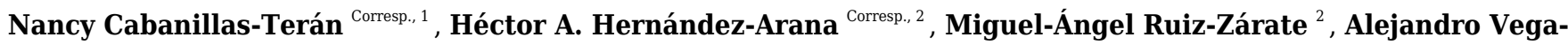 \\ Zepeda $^{2}$, Alberto Sanchez-Gonzalez ${ }^{3}$ \\ ${ }^{1}$ Consejo Nacional de Ciencia y Tecnología México- El Colegio de la Frontera Sur, Chetumal, Quintana Roo, México \\ 2 Departamento de Ecología y Sistemática Acuática, El Colegio de la Frontera Sur, Chetumal, Quintana Roo, México \\ ${ }^{3}$ Centro Interdisciplinario de Ciencias Marinas del Instituto Politécnico Nacional, La Paz, Baja California, México \\ Corresponding Authors: Nancy Cabanillas-Terán, Héctor A. Hernández-Arana \\ Email address: ncabanillas@ecosur.mx, hhernand@ecosur.mx
}

The arrival of large masses of drifting Sargassum since 2011 has caused changes in the natural dynamics of Caribbean coastal ecosystems. In the summer of 2015, unprecedented and massive mats of $S$. fluitans and $S$. natans have been observed throughout the Mexican Caribbean including exceptional accumulations ashore. This study uses stable isotopes to assess the impact of Sargassum blooms on the trophic dynamics of the Diadema antillarum sea urchin, a keystone herbivore on many Caribbean reefs. Bayesian models were used to estimate the variations in the relative proportions of carbon and nitrogen of assimilated algal resources. At three lagoon reef sites, the niche breadth of $D$. antillarum was analysed and compared under massive influx of drifting Sargassum spp. vs no influx of Sargassum blooms. The effects of the leachates generated by the decomposition of Sargassum led to hypoxic conditions on these reefs and reduced the taxonomic diversity of macroalgal food sources available to $D$. antillarum. Our trophic data support the hypothesis that processes of assimilation of carbon and nitrogen were modified under Sargassum effect. Isotopic signatures of macroalgae associated with the reef sites exhibited significantly lower values of $\delta^{15} \mathrm{~N}$ altering the natural herbivory of $D$. antillarum. The Stable Isotopes Analysis in R (SIAR) indicated that, under the influence of Sargassum blooms, certain algal resources (Dictyota, Halimeda and Udotea) were more assimilated due to a reduction in available algal resources. Despite being an abundant available resource, pelagic Sargassum was a negligible contributor to sea urchin diet. The Stable Isotope Bayesian Ellipses in R (SIBER) analysis displayed differences between sites, and suggests a reduction in trophic niche breadth, particularly in a protected reef lagoon. Our findings reveal that Sargassum blooms caused changes in trophic characteristics of $D$. antillarum with a negative impact by hypoxic conditions. These dynamics, coupled with the increase in organic matter in an oligotrophic system could lead to reduce coral reef

Peer) reviewing PDF | (2019:03:35539:2:0:NEW 16 Jul 2019) 
ecosystem function. 


\section{Sargassum blooms in the Caribbean alter the trophic structure of the sea}

\section{2 urchin Diadema antillarum}

3 Nancy Cabanillas-Terán ${ }^{1 *}$, Héctor A. Hernández-Arana*2, Miguel-Ángel Ruiz-Zárate ${ }^{2}$,

4 Alejandro Vega-Zepeda ${ }^{2}$, Alberto Sanchez-Gonzalez ${ }^{3}$

$5 \quad{ }^{1}$ Consejo Nacional de Ciencia y Tecnología México- El Colegio de la Frontera Sur, Chetumal,

6 Quintana Roo, México

7 2Departamento de Sistemática y Ecología Acuática, El Colegio de la Frontera Sur, Chetumal, 8 Quintana Roo, México

$9{ }^{3}$ Centro Interdisciplinario de Ciencias Marinas del Instituto Politécnico Nacional, La Paz, Baja 10 California, México

11 Corresponding Author:

12 Nancy Cabanillas Terán

13 Consejo Nacional de Ciencia y Tecnología México- El Colegio de la Frontera Sur, Chetumal, 14 Quintana Roo, México

15 Email address: ncabanillas@ecosur.mx +5219831648284 https://orcid.org/0000-0003-1268-5900

\section{Abstract}

The arrival of large masses of drifting Sargassum since 2011 has caused changes in the natural dynamics of Caribbean coastal ecosystems. In the summer of 2015, unprecedented and massive mats of S. fluitans and S. natans have been observed throughout the Mexican Caribbean including exceptional accumulations ashore. This study uses stable isotopes to assess the impact of Sargassum blooms on the trophic dynamics of the Diadema antillarum sea urchin, a keystone herbivore on many Caribbean reefs. Bayesian models were used to estimate the variations in the relative proportions of carbon and nitrogen of assimilated algal resources. At three lagoon reef sites, the niche breadth of $D$. antillarum was analysed and compared under massive influx of drifting Sargassum spp. vs no influx of Sargassum blooms. The effects of the leachates generated by the decomposition of Sargassum led to hypoxic conditions on these reefs and reduced the taxonomic diversity of macroalgal food sources available to D. antillarum. Our trophic data 
29 support the hypothesis that processes of assimilation of carbon and nitrogen were modified under 30 Sargassum effect. Isotopic signatures of macroalgae associated with the reef sites exhibited 31 significantly lower values of $\delta^{15} \mathrm{~N}$ altering the natural herbivory of $D$. antillarum. The Stable 32 Isotopes Analysis in R (SIAR) indicated that, under the influence of Sargassum blooms, certain 33 algal resources (Dictyota, Halimeda and Udotea) were more assimilated due to a reduction in 34 available algal resources. Despite being an abundant available resource, pelagic Sargassum was a negligible contributor to sea urchin diet. The Stable Isotope Bayesian Ellipses in R (SIBER) analysis displayed differences between sites, and suggests a reduction in trophic niche breadth, particularly in a protected reef lagoon. Our findings reveal that Sargassum blooms caused changes in trophic characteristics of $D$. antillarum with a negative impact by hypoxic conditions. These dynamics, coupled with the increase in organic matter in an oligotrophic system could lead to reduce coral reef ecosystem function.

\section{Introduction}

43 44 45 46 47 48

The arrival of massive amounts of pelagic Sargassum spp. has caused changes in the natural benthic dynamics of Caribbean coastal ecosystems for the last nine years (Gower, Young \& King, 2013; Schell, Goodwin \& Siuda, 2015). Pelagic Sargassum is a complex of two species, namely $S$. fluitans and $S$. natans (Oyesiku \& Egunyomi, 2014). Since 2011, extensive masses of Sargassum appeared in unusual ways in oceanic waters off northern Brazil (De Széchy et al., 2012; Sissini et al., 2017), along the West Indies and Caribbean coasts (Gower, Young \& King, 2013) from Trinidad to the Dominican Republic (Rodríguez-Martínez, van Tussenbroek \& Jordán-Dahlgren, 2016; van Tussenbroek et al., 2017), and along the west African coast from Sierra Leone to Ghana (Smetacek \& Zingone, 2013). Wang et al. (2019) recorded that for June 2018, wet biomass reached more than 20 million tons in the Caribbean Sea and Central Atlantic Ocean.

The Mexican Caribbean shores faced atypical massive mats of pelagic Sargassum in the summer of 2015 (van Tussenbroek et al., 2017; Cuevas, Uribe-Martínez \& Liceaga-Correa, 2018; Arellano-Verdejo, Lazcano-Hernandez \& Cabanillas-Terán, 2019). There was a subsequent decrease during 2016 and 2017, but for most of 2018 and thus far in 2019 influx has increased 
58 again. Several studies revealed that these massive mats of Sargassum have a new possible 59 distribution source different from the historic North Atlantic Recirculation Region (NARR) 60 known as "The Sargasso Sea" (Schell, Goodwin \& Siuda, 2015). Instead, the most probable 61 origin of the massive influx on the Caribbean shores is the North Equatorial Recirculation 62 Region (NERR) (Johnson et al., 2013; Schell, Goodwin \& Siuda, 2015). High oceanic 63 temperatures and nutrient inputs (Franks, Johnson \& Ko, 2016; Wang et al., 2018), among other 64 oceanographic coupled patterns such as changes of surface currents, are the most probable causes 65 of this new region of Sargassum flourishment (Johnson et al., 2013; Gower, Young \& King, 66 2013; Sissini et al., 2017). A recent study by Wang et al. (2019) revealed that increases of 67 pelagic Sargassum are driven by upwelling off West Africa during the boreal winter and by 68 Amazon River discharge during the spring and summer. The authors state that recurrent blooms 69 in the Caribbean Sea and tropical Atlantic are likely, highlighting the importance for 70 understanding their effects on existing ecosystems for future planning.

71 Changes in habitat structure can directly influence trophic dynamics (Hunter \& Price, 1992; 72 Sweatman, Layman \& Fourqurean, 2017) and have been shown to cause synergistic effects on 73 coral reefs (Smetacek \& Zingone, 2013). For example, harmful macroalgae blooms have been 74 recognized as drivers of degradation in coral reef habitats (Lapointe et al., 2005). This has effects 75 on the diversity of reef biota (Bauman et al., 2010; Louime, Fortune \& Gervais, 2017) like 76 variations in the sea urchin populations (Lapointe et al., 2010). The carbon and nitrogen flow by 77 macroalgae blooms likely has adverse effects at different scales. Such disturbances from 78 Sargassum, coupled with pre-existing threats on coral reefs, add to the drivers of Anthropocene 79 reef degradation (Alvarez-Filip et al., 2011; Cramer et al., 2012).

80 The massive decomposition of Sargassum has negative impacts not only on tourism and local 81 fisheries, but on nearshore ecosystems (Solarin et al., 2014; Louime, Fortune \& Gervais, 2017). 82 However, few studies assess the trophic impact of Sargassum blooms on benthic communities. 83 Pelagic Sargassum and their attached epiphytic algae can contribute new organic matter to these 84 communities (Rooker, Turner \& Holt, 2006; Wang et al. 2018). Therefore, we consider whether 85 or not these new sources of nitrogen and carbon act in a detrimental manner on the trophic chain 86 of benthic communities. The beaching and decomposing of massive Sargassum mats produce 87 hypoxia in near-shore coral reef communities (Rodríguez-Martínez et al. 2019). This effect 
88 coupled with high hydrogen sulfide and ammonium concentrations have been shown to cause 89 faunal mortality in the Mexican Caribbean (Rodríguez-Martínez et al. 2019). As a consequence, 90 the coastal environment becomes even more sensitive to degradation agents. To assess these 91 issues, we included measurements of dissolved oxygen in our study.

92 Evaluating consumers and resources through a trophic approach by tracking the relationships 93 between consumers and prey provides relevant information on the trophic structure and 94 dynamics of a benthic community (Minagawa \& Wada, 1984; Vanderklift, Kendrick \& Smit, 95 2006; Behmer \& Joern, 2008). Stable isotopes of carbon $\left(\delta^{13} C\right)$ and nitrogen $\left(\delta^{15} N\right)$ have been 96 used in marine ecosystems to determine the feeding habits of species (Peterson \& Fry, 1987), 97 nutrient migrations within food webs, trophic position of organisms and their contribution at all 98 trophic levels (Vander Zanden \& Rasmussen, 1996). It is also possible to trace the origin and 99 transformation of the ingested organic matter and to detect changes in the trophic positions of 100 organisms that coexist in the same habitat (Hobson, 1999; Vanderklift, Kendrick \& Smit, 2006;

101 Rodríguez-Barreras et al., 2016).

102 Stable carbon and nitrogen isotope ratios provide time-integrated information regarding feeding 103 relationships and energy flow through food webs (DeNiro \& Epstein, 1981; Peterson \& Fry, 104 1987; Vander Zanden \& Rasmussen, 2001). Moreover, stable isotopes can be used to study the 105 trophic niche breadth of a species (Bearhop et al., 2004; Parnell et al., 2010; Phillips et al., 2014).

106 This is directly influenced by consumers and resource input, providing a quantitative assessment 107 of trophic conditions (Newsome et al. 2007; Boecklen et al. 2011). Stable isotope analyses are 108 useful for assessing the health of ecosystems because it is possible to associate the consumers 109 trophodynamics and niche breadth with habitat disturbances (Layman et al., 2007b; Hamaoka et 110 al., 2010). It is also possible to detect changes in the trophic spectrum from anthropogenic 111 impacts or unusual conditions that cause shifts in ecosystems (Wing et al., 2008; Prado, 112 Alcoverro \& Romero, 2010; Tomas, Box \& Terrados, 2011). In light of the massive arrival of 113 pelagic macroalgae, sea urchin herbivory is a good model to understand variability in the benthic 114 trophic chain, as sea urchins are considered generalist consumers with a plastic feeding habit 115 (Lawrence, 1975; Vanderklift, Kendrick \& Smit, 2006). Echinoids have the capability to modify 116 the community structure through foraging behaviour (Carpenter, 1986; Hay \& Fenical, 1988; 117 Sala et al., 1998; Eklöf et al., 2008). Thus, the relative position of $\delta^{13} \mathrm{C}$ vs $\delta^{15} \mathrm{~N}$ echinoids 
118 displayed in a bi-plot can give insights about organism responses to niche shifts, diet variability 119 and habitat modification (Layman et al., 2007a,b, 2012; Sweatman, Layman \& Fourqurean, 120 2017).

121 The effect of Sargassum and their leachates on the diet of D. antillarum can improve our 122 understanding on the impact on trophic ecology of one of the most important sea urchins of the 123 Mexican Caribbean. The main reason to focus this study on D. antillarum is that this species is 124 and was the major shallow-hard-bottom grazer in our study sites (Jorgensen, Espinoza-Ávalos \& 125 Bahena-Basave, 2008; Jordán-Garza et al., 2008). One of the most dramatic events in the 126 Caribbean resulted from the pathogen-driven reduction in the populations of D. antillarum 127 (Lessios et al., 1984) with detrimental ecological consequences like coral-algal phase-shifts. The 128 southern part of Quintana Roo is not an exception encompassing with the effects of the abrupt 129 coastal development and watershed pollution as key drivers along the Costa Maya (Arias130 González et al., 2017).

131 The overarching aim of this study was to determine variations in the relative proportions of 132 carbon and nitrogen of assimilated algal resources and the niche breadth of $D$. antillarum under 133 massive influx of drifting Sargassum spp. vs no influx of Sargassum at back reefs. We also 134 aimed to determine whether pelagic Sargassum was a substantial source of energy for $D$. 135 antillarum. To do this, we compared $\delta^{15} \mathrm{~N}$ and $\delta^{13} \mathrm{C}$ values of $D$. antillarum with and without 136 influx of Sargassum to track changes in this species trophic ecology (diet, trophic position and 137 niche breadth). Ultimately, we tested the hypothesis that an influx in Sargassum in coastal 138 ecosystem creates a significant change in the available algal sources and a shift in the trophic 139 structure.

\section{Material \& Methods}

\section{Study sites}

142 We determined the stable isotopes of carbon and nitrogen for D. antillarum at three reef lagoons 143 (Mahahual, Xahuayxol, and Xcalak) with different distances from the beach to the reef crest

144 (Figure 1). The main strategy implemented by local authorities at some beaches with the massive 145 arrival of macroalgae included the removal and disposal of Sargassum in the highest part of the 146 beach or in places determined ex profeso. This contributed to a continuous accumulation of 
147 Sargassum masses on the beach. However, the Sargassum removal was not quantified and the

148 information regarding removal included here is only preliminary.

149 Mahahual $\left(18^{\circ} 42^{\prime} 16.96^{\prime \prime} \mathrm{N} 87^{\circ} 42.619^{\prime} \mathrm{W}\right)$ is located in the northern part of the Mesoamerican 150 Barrier Reef System (MBRS) in the state of Quintana Roo. Mahahual is a former fishing village

151 but during the last two decades has undergone reef degradation due to anthropogenic impact 152 (Martínez-Rendis et al., 2016). It has a narrow reef lagoon (230-450 m). Sargassum management 153 in this locality was active through removing it from the beach and ex situ disposition.

154 Xahuayxol (18³0'21.78"N; 8745'24.84"W) located south of Mahahual, has a larger reef lagoon 155 measuring 300 to $500 \mathrm{~m}$ from the beach to the reef crest. Sargassum was not removed from the 156 beach in any systematic way and remained accumulated on the shore. This reef is the northern 157 limit of the marine protected area Parque Nacional Arrecifes de Xcalak (PNAX) and human 158 activities are less salient than in Mahahual (Schmitter-Soto et al., 2017).

159 Xcalak $\left(18^{\circ} 14^{\prime} 7.68^{\prime \prime N}\right.$; 87 $\left.50^{\prime} 1.46^{\prime \prime W}\right)$, at the southern limit of the Mexican Caribbean, is part of 160 PNAX since 2000. It is also part of the MBRS (Hoffman, 2009). It has a wide reef lagoon (950$1611200 \mathrm{~m}$ ), and Sargassum was accumulated along the shore in large amounts. There was active 162 but less intense Sargassum management in place at Xcalak, where final disposal was in situ on 163 the highest part of beach.

164 At all sampled sites, the dominant forcing mechanism was reef lagoon circulation from wave 165 action (Mariño-Tapia et al., 2011). In our study area, during the period from June to August has 166 the wave orbital velocity over the threshold of motion (Maldonado-Sánchez et al. 2019), 167 indicating active circulation in the reef lagoons.

\section{Collecting and processing data}

169 This study covers two periods: Under Sargassum effect (USE) during the months of July-August 1702015 and without Sargassum effect (WSE) in July-August 2016. USE sampling for stable 171 isotope analysis included drifting Sargassum (mixture of S. fluitans and S. natans), turf 172 associated-pelagic Sargassum, benthic macroalgae, local turf and 19 individuals of D. antillarum. 173 WSE sampling included benthic macroalgae, local turf and 15 individuals of $D$. antillarum (see 174 sampling details ST1). Samples sizes were based on previous studies to obtain sufficient data for 
175 statistical analysis (Rodríguez, 2003; Tomas et al., 2006; Wing et al., 2008; Rodríguez-Barreras

176 et al., 2016). The sampling sites were at coastal lagoons in the back reef zone (section c, Fig. 2),

177 zone with no visible presence of Sargassum leachates (van Tussenbroek, et al. 2017) and where

178 D. antillarum is distributed (Steneck \& Lang, 2003; Jorgensen, Espinoza-Ávalos \& Bahena-

179 Basave, 2008; Jordán-Garza et al., 2008; Maldonado-Sánchez, 2018).

180 Under Sargassum Effect (USE) measurements

181 USE included measurements of dissolved oxygen $\left(\mathrm{mg} \mathrm{l}^{-1}\right)$ recorded with a calibrated Multi182 parameter water quality checker HORIBA 50 at Mahahual, Xahuayxol and Xcalak. 183 Measurements of dissolved oxygen were made at points distributed in three sections from areas 184 with decomposing Sargassum (section a), leachates (section b -dark brown water-) and reef 185 lagoon areas without Sargassum leachates (section c) (Figure 2).

186 Pelagic Sargassum spp., turf (benthic turf and the associated turf to pelagic Sargassum) and 187 macroalgae samples were collected in coral reef patches of section c (back reef zone) for each 188 sampling site.

\section{Under and Without Sargassum Effect (USE and WSE) measurements}

190 We collected algal samples to obtain biomass, and for stable isotope analysis using nine quadrats 191 (50 x $50 \mathrm{~cm})$ per site. Pelagic Sargassum biomass was calculated based on sunken thalli and 192 overlaid on reef substrates inside the quadrats. The quadrats were located randomly within the 193 sea urchin habitat (radius of $15 \mathrm{~m}$ from collected echinoids). The substrate inside each quadrat 194 was scrapped, carefully removed, collected in bags, and frozen for later analysis.

195 Macroalgae were identified according to Littler and Littler (2000). Analyses were performed to 196 genus level. For biomass estimates samples were dried for $48 \mathrm{~h}$ in an oven at $60^{\circ} \mathrm{C}$. Samples were 197 weighed with a digital balance (standard error $=0.0001 \mathrm{~g}$ ). To determine D. antillarum 198 differential algae assimilation considering USE and WSE, algae samples were pooled per site.

199 The sampled echinoids and algal species for this study are not threatened. The collection permit 200 was obtained from the Comisión Nacional de Acuacultura y Pesca (CONAPESCA, 201 PPF/DGOPA-002/17). 
202 The collected individuals of $D$. antillarum were at the same depth range $(1.5-2.5 \mathrm{~m})$ and only 203 individuals greater than $5.0 \mathrm{~cm}$ in test diameter were collected to avoid any ontogenic effect. 204 Samples were frozen shortly after collection and processed later at the laboratory. The muscles 205 of Aristotle's lanterns were carefully removed and washed from the stomach contents to estimate 206 algal assimilation by $D$. antillarum because this tissue offers a time-integrated measure of carbon 207 and nitrogen assimilated sources (Polunin et al., 2001; Ben-David \& Schell, 2001; Phillips \& 208 Koch, 2002).

209 Macroalgae and local turf, pelagic Sargassum species (S. fluitans and S. natans), turf associated 210 to pelagic Sargassum, and echinoids muscle samples were rinsed with filtered water, dried at $50^{\circ}$ $211 \mathrm{C}$ during $48 \mathrm{~h}$, grounded to a fine powder and placed in glass vial for isotope analyses. To 212 remove carbonates from some algal species (eg., Halimeda spp. Penicillus spp., etc), the samples 213 were washed with diluted $\mathrm{HCl}$ at $1 \mathrm{~N}$ prior to drying to avoid disturbance in the mass 214 spectrometer reading.

215 A subsample of each algae and muscle $(1 \mathrm{mg})$ was taken to evaluate the ${ }^{13} \mathrm{C} /{ }^{12} \mathrm{C}$ and ${ }^{15} \mathrm{~N} /{ }^{14} \mathrm{~N}$ 216 ratios using a Delta V Plus Mass Spectrometer. Catalyzers silvered cobaltous/cobaltic oxide and 217 chromium oxide were used. Carbon and nitrogen samples were analysed in a dual isotope mode 218 at the Centro Interdisciplinario de Ciencias Marinas from Instituto Politécnico Nacional. Isotope 219 samples were loaded into tin-capsules and placed in a 50-position automated Zero Blank sample 220 carousel on a COSTECH 4020 elemental analyzer. The carbon and nitrogen isotopic results were 221 expressed in standard delta notation relative to Vienna Pee Dee Belemnite (VPDB) and to 222 atmospheric air.

223

$\delta 13_{\mathrm{C}}=\left\lfloor\left(\frac{\left(\frac{13_{\mathrm{C}}}{12_{\mathrm{C}}}\right) \text { Sample }}{\left(\frac{13_{\mathrm{C}}}{12_{\mathrm{C}}}\right) \text { Standard }}\right\rfloor-1\right) \times 1000(\% 0)$ 
224 and

225

$\left.\delta 15_{\mathrm{N}}=\left\lfloor\frac{\left(\frac{15_{\mathrm{N}}}{14_{\mathrm{N}}}\right) \text { Sample }}{\left(\frac{15_{\mathrm{N}}}{14_{\mathrm{N}}}\right) \text { Standard }}\right\rfloor-1\right\rfloor \times 1000(\% 0)$

226

227 The standard deviations of $\delta 13 \mathrm{C}$ and $\delta 15 \mathrm{~N}$ replicate analyses were estimated; the precision 228 values were $0.2 \%$ for carbon and nitrogen isotope measurements. In addition, we calculated the 229 trophic level (TL) according to Hobson and Welch (1992) for every individual of D. antillarum 230 in each site, expressed as:

$$
\mathrm{TL}=\frac{1+(\mathrm{Nm}-\mathrm{Nb})}{\mathrm{TEF}}
$$

232 Where $\mathrm{Nm}$ is the mean $\delta^{15} \mathrm{~N}$ ratio of each sea urchin, $\mathrm{Nb}$ is average basis $\delta^{15} \mathrm{~N}$ value of the algal 233 community, and TEF is the given value for the trophic enrichment factor (TEF). We assumed a 234 TEF of 2.4 following Moore and Semmens (2008).

\section{Data analysis}

236 Dissolved oxygen data were summarized to obtain average values ( \pm standard error) by section 237 (a, b, c in Figure 2) and reef lagoons (Mahahual, Xahuayxol, and Xcalak). We evaluated 238 differences among sections and at the reef lagoons ( $a, b$, c, in Figure 2). We plotted raw data of 239 dissolved oxygen as a function of distance to coast to visualize the low to high values gradient related to that distances in every reef lagoon.

241 The relative contribution of algae to the diet of the sea urchins $D$. antillarum was estimated with

242 a Bayesian isotopic mixing model (SIAR, Parnell \& Jackson, 2013), which included the isotopic 243 signatures, fractionation and variability to estimate the probability distribution of the contribution 244 of the food source to a mixture. This procedure supplied accurate information about the 245 contribution of algal species to the sea urchin tissues, as it provided the proportion for every 246 source and recognized the main sources as important components of the diet (Peterson, 1999; 247 Fry, 2006; Wing et al., 2008) at three different sites, and under and without Sargassum effect. To 
248 run the model, the isotopic discrimination factor values used were $2.4 \pm 1.6 \%$ (mean $\pm \mathrm{SD}$ ) for

$249 \delta^{15} \mathrm{~N}$, and $0.4 \pm 1.3 \%$ (mean $\pm \mathrm{SD}$ ) for $\delta^{13} \mathrm{C}$ (Minagawa \& Wada, 1984; Fry \& Sherr, 1989;

250 Moore \& Semmens, 2008; Cabanillas-Terán et al., 2016).

251 The following algal taxa/groups were considered for the mixing models analyses: Caulerpa,

252 Codium, Dictyota, Halimeda, Laurencia, Lobophora, Padina, Penicillus, Sargassum

253 polyceratum, Stypopodium, turf, and Udotea. The sources for the model were selected following

254 the theoretical geometric assumptions of the mixing model according to Phillips et al. (2014) and

255 Rodríguez-Barreras et al. (2015) to ensure reliable resources. Samples of D. antillarum did not 256 require lipid extraction since $\mathrm{C}: \mathrm{N}$ ratios of Aristotle lantern's muscle were lower than 3.5 (Post 257 et al., 2007).

258 We performed a comparison USE and WSE between the niche width and overlap for $D$. 259 antillarum by using Stable Isotope Bayesian Ellipses in R (SIBER) (Jackson et al., 2011) from 260 the SIAR package (Parnell \& Jackson, 2013). This procedure performs metrics based on ellipses 261 and provides the standard ellipse corrected area (SEAc) used as the trophic niche breadth and the 262 overlap between ellipses, presuming that values close to 1 exhibit a higher trophic overlap. 263 Models were run with 200000 iterations and a burn in of 50000.

264 Homogeneity and normality of variance were tested by performing a Kolmogorov-Smirnov and a 265 Cochran's test (Zar, 1999). Nitrogen data followed the premises of parametric analysis, but the 266 carbon, dissolved oxygen and biomass data required a power transformation for reaching 267 normality and homogeneity of variance (Box \& Cox, 1964). We ran two-way ANOVA to 268 evaluate dissolved oxygen data differences among sections in the reef lagoons and we performed 269 a post hoc comparison using Tukey-HSD test. The functions aov and glm from the Gaussian 270 family were used to test the differences in isotopic ratios of carbon and nitrogen values to 271 compare the effect (WSE and USE) between sites and their interaction. Statistics were performed 272 with $\alpha<0.05$ (R Core Team, 1.0.153, 2017).

\section{Results}

274 The dissolved oxygen values USE indicated that the effects of the leachates generated by the 275 decomposition process, together with the organic material carried in their vegetal structures, 276 reduced the values of dissolved oxygen in the reef lagoon water. The decomposing Sargassum 
277 area (section a, Figure 2) showed an average range from 1.01 (S.E. \pm 0.30$) \mathrm{mg} \mathrm{l}^{-1}$ at Xcalak to

2781.88 (S.E. \pm 0.37$) \mathrm{mg}^{-1}$ at Mahahual. The leachates area (section b, Figure 2) showed an 279 average range from 2.42 (S.E. \pm 0.32$) \mathrm{mg}^{-1}$ at Xahuayxol to 3.66 (S.E. \pm 0.42 ) $\mathrm{mg}^{-1}$ at

280 Mahahual. The back reef area (section c, Figure 2) showed an average range from 4.1 (S.E. \pm $2810.34) \mathrm{mg}^{-1}$ at Mahahual to $4.8($ S.E. \pm 0.22$) \mathrm{mg}^{-1}$ at Xcalak. The two-way ANOVA indicated 282 significant differences between reef lagoons $(\mathrm{p}<0.05)$ and sections $(\mathrm{p}<0.01)$; Mahahual was 283 significantly different to Xcalak, but Mahahual and Xcalak were not significantly different to 284 Xahuayxol (Post-hoc HSD of Tukey test, 95\% confidence). The three sections at the three reefs 285 were significantly different, except the sections b and c of Mahahual (Post-hoc HSD of Tukey 286 test, 95\% confidence). Therefore dissolved oxygen data showed a gradient significantly different 287 between sections. The overall values of dissolved oxygen displayed the lowest concentrations for 288 section a, near the shoreline and higher values beyond the back reef section c (Figure 3 ).

289 Biomass, $\boldsymbol{\delta}^{15} \mathbf{N}$ and $\delta^{13} \mathbf{C}$ of macroalgae

290 Biomass data for benthic taxa displayed no significant differences between USE and WSE, but 291 significant differences were found among localities (ANOVA, $\mathrm{df}=2, \mathrm{~F}=8.24, p<0.0001$ ). 292 Mahahual had the highest mean benthic biomass values (55.2 dry weight $\mathrm{m}^{-2}$ ) followed by 293 Xahuayxol with (38.8 dry weight $\mathrm{m}^{-2}$ ) and Xcalak (16 dry weight $\mathrm{m}^{-2} \pm$ ). WSE biomass average 294 values for local benthic algae ranged from 3.01 dry weight $\mathrm{m}^{-2} \pm 0.95$ (Codium spp. at Xcalak) to 295133.50 dry weight $\mathrm{m}^{-2} \pm 30.29$ (Halimeda spp. at Mahahual). USE values ranged from 7.75 dry 296 weight $\mathrm{m}^{-2} \pm 5.4$ (Caulerpa at Xcalak) to 145.99 dry weight $\mathrm{m}^{-2} \pm 36.21$ (Halimeda spp. at 297 Mahahual, Table 1). Genus-level biomass of pelagic taxa showed no significant differences per 298 site neither at genus level, however Sargassum fluitans displayed the highest biomass values.

299 Under and without Sargassum effect values revealed significant differences in overall benthic 300 algae values of $\delta^{15} \mathrm{~N}$ (ANOVA, $\mathrm{df}=1, \mathrm{~F}=20.27, p<0.0001$ ). Specifically under Sargassum blooms 301 most of the algae exhibited isotopic signatures with significantly depleted $\delta^{15} \mathrm{~N}$ like Dictyota and 302 turf across the lagoon reef sites (Table 2). The overall macroalgal $\delta^{15} \mathrm{~N}$ under Sargassum 303 fluctuated from 0.023 to 2.08\% . At Xcalak Caulerpa displayed the highest mean values of 304 nitrogen with $2.02 \pm 0.08 \%$. Local Turf USE displayed negative values and overall turf values 305 fluctuated from $-0.97 \%$ to $0.42 \%$. Xahuayxol displayed the most negative $\delta^{15} \mathrm{~N}$ mean value of 306 local turf $\left(-0.51 \pm 0.02 \%\right.$ ). Without Sargassum effect the mean algal genus $\delta^{15} \mathrm{~N}$ fluctuated from 
$3070.06 \pm 0.08$ with Penicillus at Xcalak, and Xahuayxol displayed the highest mean value of $\delta^{15} \mathrm{~N}$ 308 with Caulerpa (5.68 $\pm 0.01 \%)$ (Table 2).

309 As for $\delta^{13} \mathrm{C}$ USE ratios fluctuated from -21.98 to $-9.23 \%$ and WSE from -20.90 to $-5.65 \%$. 310 Considering only the algae presented in both sampling periods (WSE and USE) there was no 311 significant difference in $\delta^{13} \mathrm{C}$ among sites (ANOVA, $\mathrm{df}=2, \mathrm{~F}=0.55, p>0.05$ ) neither was 312 significant difference analysing the effect (ANOVA, $\mathrm{df}=1, \mathrm{~F}=1.14, p>0.05$ ) and their interaction 313 (ANOVA, df=2, $\mathrm{F}=0.86, p>0.05$ ).

314 Overall USE pelagic Sargassum $\delta^{13} \mathrm{C}$ values fluctuated from $-17.95 \%$ to $-15.24 \%$. S. natans 315 exhibited the most negative mean values of $\delta^{13} \mathrm{C}(-17.44 \pm 0.71 \%$ ) at Mahahual (Table 2). There 316 was no difference in $\delta^{13} \mathrm{C}$ among sites (ANOVA, $\mathrm{df}=2, \mathrm{~F}=0.05, p>0.05$ ) but there were 317 significant differences $\delta^{13} \mathrm{C}$ between species (ANOVA, $\mathrm{df}=2, \mathrm{~F}=7.57, p=0.01$ ). Sargassum's 318 associated turf $\delta^{13} \mathrm{C}$ values fluctuated from $-18.65 \%$ o to $-15.37 \%$. The most negative $\delta^{13} \mathrm{C}$ mean

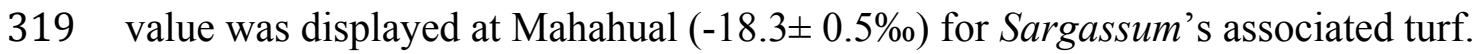

320 Overall pelagic Sargassum $\delta^{15} \mathrm{~N}$ values ranged from $-2.87 \%$ o to $-0.30 \%$. The less negative mean 321 value was exhibited at Mahahual (-0.53 $\pm 0.26 \%$ ) for $S$. fluitans. There was no significant 322 difference for $\delta^{15} \mathrm{~N}$ among sites (ANOVA, $\mathrm{df}=2, \mathrm{~F}=3.90, p=0.05$ ), but there was a remarkable 323 trend to depleted $\delta^{15} \mathrm{~N}$ at Xcalak where $S$. fluitans displayed the lowest mean values of $\delta^{15} \mathrm{~N}$ ($3242.51 \pm 0.52 \%$ ). Turf associated to floating Sargassum $\delta^{15} \mathrm{~N}$ values fluctuated from $-0.42 \%$ to 325 1.17\%o. The most depleted $\delta^{15} \mathrm{~N}$ was exhibited at Mahahual $(-1.13 \pm 0.05 \%$ ) and the less negative 326 mean value was displayed in Xahuayxol (-0.47 $\pm 0.07 \%$ ).

\section{Sea urchins}

328 There were significant differences $\delta^{15} \mathrm{~N}$ among sites (ANOVA $\mathrm{df}=2, F=6.473, p=0.005$ ) and the 329 interaction between site*effect (USE and WSE) showed significant differences (ANOVA, df =2, $330 \quad \mathrm{~F}=7.321, p=0.003)$.

331 D. antillarum exhibited no differences among sites for $\delta^{13} \mathrm{C}$ values $p>0.05$. However, we found 332 significant differences analysing the USE and WSE effect (ANOVA $\mathrm{df}=1, \mathrm{~F}=5.301, p=0.03$ ). 333 The isotopic ratios of $D$. antillarum (USE) varied from $3.83 \%$ to $6.13 \%$ or for $\delta^{15} \mathrm{~N}$, while $\delta^{13} \mathrm{C}$ 334 ranged from $-9.41 \%$ o to $-13.62 \%$. Mahahual was the site with the highest average values for $\delta^{15} \mathrm{~N}$ 
$3355.80 \pm 0.30 \%$, while Xcalak displayed the lowest average value $4.38 \pm 0.29 \%$. The isotopic 336 ratios of $D$. antillarum (WSE) ranged from $4.69 \%$ o to 6.16 for $\delta^{15} \mathrm{~N}$, while $\delta^{13} \mathrm{C}$ fluctuated from $3378.83 \%$ o to $-13.42 \%$. We found significant differences for $\delta^{15} \mathrm{~N}$ for sea urchins between sites 338 (USE, ANOVA, df=2, $\mathrm{F}=6.47, p<0.005$ ).-Xcalak showed particularly low values under 339 Sargassum effect (average value $4.38 \pm 0.29 \%$ versus WSE average value $5.44 \pm 0.36 \%$ ). 340 Nevertheless, $\delta^{13} \mathrm{C}$ exhibited no significant differences although we noticed a negative trend in 341 the values of $\delta^{13} \mathrm{C}$ under Sargassum effect (USE).

342

343 Algal source contributions (SIAR)

344 Mixing models provided evidence for the contribution of different algal resources for three sites 345 USE and WSE (Table 3). SIAR analysis showed that D. antillarum behaved as an opportunistic 346 grazer under the Sargassum effect, it is important to note that pelagic Sargassum, despite being 347 one of the most abundant available resources, was not the most assimilated resource (Figure 4). 348 Relatedely, there was a reduction in benthic food sources USE (Figure 4). Without Sargassum 349 effect D. antillarum consumed, Laurencia, Stypopodium and Udotea (12-15\% in average) at 350 Mahahual; Caulerpa, Laurencia, Penicillus, Sargassum and Stypopodium (8-14 \% in average) at 351 Xahuayxol; and Codium, Lobophora and Padina (13-15\% in average) at Xcalak. Nevertheless, 352 those resources were absent in the diet of D. antillarum under Sargassum effect (Table 3). 353 Hence, the species displayed differential resource assimilation and Caulerpa was the most 354 important resource for D. antillarum in Mahahual WSE (up to 37\%), followed by Turf (up to 355 34\%) and Halimeda and Udotea (up to 29\% for both). USE the most important resource was 356 Halimeda (up to $44 \%$ ) followed by Caulerpa and Dictyota (both up to $31 \%$ of contribution). S. 357 fluitans and $S$. natans were no important sources (0-28\% and 0-23\% respectively), and turf 358 associated to Sargassum blooms was the lesser assimilated resources by D. antillarum from 0 up 359 to $22 \%$ (Table 3).

360 At Xahuayxol WSE D. antillarum showed Caulerpa was the most important resource for $D$. 361 antillarum (from 2 up to 25\%) and for the rest of algae there were very similar algal contribution 362 (from 0 up to 23\%). The main macroalgal contributor of USE was Udotea with up to 61\%, 363 followed by Halimeda and Lobophora (with up to 35\% and 38\% respectively) as secondary 364 resources. Sargassum's associated turf showed evidence of low contribution (from 0 up to 21\%) 365 and $S$. fluitans, $S$. natans had negligible contribution to D. antillarum diet with a maximum of 
$36617 \%$ of the proportional contribution (Table 3).

367

368 Turf was the main algal resources for D. antillarum in Xcalak WSE (up to 45\%) followed by 369 Caulerpa, Codium and Padina as secondary resources (close to 30\% maximum of contribution); 370 contrasting USE the main macroalgal contributors in Xcalak were Penicillus and Caulerpa with 371 up to $39 \%$ and $40 \%$ respectively. Likewise Dictyota and Sargassum polyceratium (benthic 372 Sargassum) were secondary resources up to $26 \%$ and $29 \%$, respectively. The pelagic components 373 in the other reef lagoons were negligible contributors for D. antillarum diet with just 18-23\% of 374 maximum contribution (Table 3, Figure 4).

375

\section{Trophic Levels}

377 The overall trophic level data for D. antillarum (TL) ranged from 1.97 to 3.22. The species 378 exhibited significant differences among sites (ANOVA df=2, $\mathrm{F}=10.63, p=0.0004$ ), and exhibited 379 significant differences between WSE and USE (ANOVA, $\mathrm{df}=1, \mathrm{~F}=17.7, p=0.0003$ ). Likewise, 380 calculating the interaction between site*effect (USE and WSE) revealed significant differences 381 (ANOVA, $\mathrm{df}=2, \mathrm{~F}=12.65, p=0.0001$ ). The highest TL values were reported for Mahahual USE, 382 while the lowest one was recorded in Xahauayxol WSE. At Mahahual, the TL mean value of $D$. 383 antillarum was $2.35 \pm 0.18$ WSE and $3.08 \pm 0.13$ USE; at Xahuayxol, the TL mean value was 384 $2.13 \pm 0.30$ WSE and 2.49 \pm 0.27 USE, and at Xcalak TL mean value was $2.62 \pm 0.15$ WSE and 385 $2.45 \pm 0.12$ USE (Table 4).

386

387

388

\section{Isotopic Niches}

Table 5 shows data on isotopic niche breadth as measured by the corrected standard ellipse area (SEAc). The Stable Isotope Bayesian Ellipses in R (SIBER) analysis suggested a reduction in trophic niche particularly in Xcalak. This site showed the main difference in the trophic niche

392 between WSE and USE was only found in Xahuayxol (Figure 5). SEAc was higher USE in this 393 site with 3.57 versus 2.68 SEAc WSE (Figure 5).

\section{Discussion}

395 Our results provide evidence of the detrimental effect of Sargassum blooms on the 
396 physicochemical water properties and ecological processes in near-shore coral reef communities

397 as recently has been identified in our study area (Rodríguez-Martínez, van Tussenbroek \& 398 Jordán-Dahlgren, 2016; van Tussenbroek et al., 2017; Cuevas, Uribe-Martínez \& Liceaga399 Correa, 2018). Particularly, the results provide evidence for the input of external carbon and 400 nitrogen resulting from Sargassum blooms on benthic communities that altering the nutrient 401 inputs and trophic niche for D. antillarum. These findings contribute to the growing recognition 402 of the role of exogenous nutrient enrichment in modifying natural sources in a food web. Hence 403 the organic matter inputs from Sargassum coupled with hypoxia leads to modification of natural 404 algal resources for $D$. antillarum. Considering the detrimental effects this likely represents a 405 nutrient limitation to sea urchin herbivory.

406 Onshore Sargassum exhibits physical processes of fragmentation, decomposition and 407 remineralization by bacteria, meiofauna and grazers (Colombini \& Chelazzi, 2003). The algae408 derived organic matter, product of that decomposition, has an effect on in situ oxygen 409 availability (Haas et al., 2010). Sargassum blooms clearly showed a negative impact hypoxic 410 conditions found at the three studied reef lagoons (Figure 3). This could ultimately drive the 411 success of the communities' nitrogen fixation, evidenced by depleted values of $\delta^{15} \mathrm{~N}$ as reported 412 by Dorado et al. (2012) and France (1995).

413 The dissolved oxygen values in the back reefs of our study areas were lower than the standard 414 values for coral reefs dominated by algae $\left(7.9 \pm 0.5 \mathrm{mg}^{-1}\right)$ according to Haas et al. (2010) and 415 values reported by Camacho-Cruz et al. (2019) for Xahuayxol and Mahahual. This supports 416 ideas from Kendrick et al. (2000) and Haas et al. (2010), who argue that benthic communities 417 linked to reef lagoons are very susceptible to environmental degradation. Some benthic algae 418 play an important play in the transfer of energy and can be catalyzers of oxygen dynamics in 419 reefs due to coral reef associated algae-derived organic matter (Wild et al. 2010).

\section{Isotopic variations in the algal resources}

421 We found that the composition of benthic macroalgae assemblages were different under 422 Sargassum and without Sargassum effect. USE showed a reduction in the taxonomic diversity of 423 macroalgal food sources available to D. antillarum and isotope values presented substantially 424 lower $\delta^{15} \mathrm{~N}$ values (Table 2). The fact that there were fewer available algal sources in the USE 425 condition implies that the trophic chain becomes less complex as the interaction of primary 
426 consumers with their resources is reduced (Phillips \& Gregg, 2003).

427

428 Overall $\delta^{13} \mathrm{C}$ values ranged from -21.98 to $-5.65 \%$ are similar to ranges reported by Fry \& Sherr

429 (1984) and Morillo-Velarde et al. (2018). Those authors reviewed the $\delta^{13} \mathrm{C}$ data of benthic algae, 430 noting that values ranged between -30 and $5 \%$. $\delta^{15} \mathrm{~N}$ overall algae values fluctuated from 0.02 to $4315.68 \%$. Despite these values agree with the variation reported in other studies like Owens (1987) 432 and France (1995), we found USE very low, ergo according to Lapointe et al. (2005) and France 433 et al. (1998). These low ${ }^{15} \mathrm{~N}:{ }^{14} \mathrm{~N}$ ratios can be indicative of macroalgae living in oligotrophic 434 reefs which experience nitrogen fixation (Montoya et al., 2002). In the presence of the leachates 435 of decomposing Sargassum, it is possible that anaerobic bacteria gained significance over other 436 benthic groups (Table 2), (Carpenter \& Cox, 1974; Rooker, Turner \& Holt, 2006), and could be 437 the cause of the low macroalgal isotopic signatures. On the other hand, high values of $\delta^{15} \mathrm{~N}$ in 438 macroalgae are linked to land-based $\mathrm{N}$ enrichment sources, being a good indicator of 439 anthropogenic nitrogen inputs (Umezawa et al., 2002) such as sewage discharges (Risk et al., 440 2009; Lapointe et al., 2011).

441 France (1995) reported nitrogen ranges of marine macroalgae from -3 to $18 \%$. The 442 inconsistencies in this pattern with values of $\delta^{15} \mathrm{~N}$ close to atmospheric signature of $0 \%$ suggest a 443 fixation of nitrogen. Dorado et al. (2012) associated the depleted values of $\delta^{15} \mathrm{~N}$ with nitrogen 444 fixation and its impact on the trophic position of consumers. So, temporal difference between 445 values in this study WSE and USE might be explained by the influence of organic input derived 446 from floating Sargassum dragged components. We considered that it is likely that the Sargassum 447 effect modifies organic matter dynamics. These modifications stem from changes in the oxygen 448 levels, which were consistently reflected in the low $\delta^{15} \mathrm{~N}$ values we recorded of for the primary 449 producers.

\section{Status of Diadema antillarum in the Mexican Caribbean}

451 It is important to note that we focused our study on the most abundant species at the three 452 localities and the most important shallow-bottom herbivore on Caribbean reefs (Carpenter, 1981; 453 Hughes, 1994; Aronson \& Precht, 2006; Kissling et al., 2014). For the Mexican Caribbean, there 454 has been considerable variation in D. antillarum population data. Jordán-Garza et al. (2008) 455 showed a high presence of $D$. antillarum with densities of more than 7 ind $\mathrm{m}^{-2}$ in several areas, 
456 including our study area. Jorgensen et al. (2008) reported densities of $12.6 \mathrm{ind} \mathrm{m}^{-2}$ after hurricane 457 Dean. According to Maldonado-Sánchez (2018) population density of D. antillarum displayed $458<1$ ind $\mathrm{m}^{-2}$ for five different habitats of the Parque Nacional Arrecifes de Xcalak (PNAX) reef 459 lagoon (back reef, seagrasses, sandy bottoms and reef patches) and the fore reef. The back reef 460 exhibited the highest abundance with an average of 0.5 ind $\mathrm{m}^{-2}$. However for Mahahual, we 461 registered an average density of 0.6 ind $\mathrm{m}^{-2}$ (Cabanillas-Terán, personal observations), because 462 of the broad variability exhibited in D. antillarum populations from the back reef.

\section{Trophic parameters of $\boldsymbol{D}$. antillarum}

464 Our results support the evidence that Sargassum blooms impacted $\delta^{15} \mathrm{~N}$ differentially among 465 sites, as the ratios of $\delta^{15} \mathrm{~N}$ and $\delta^{13} \mathrm{C}$ are determined by their resources (Phillips \& Gregg, 2003). It 466 was conspicuous that D. antillarum showed higher $\delta^{15} \mathrm{~N}$ values USE at Mahahual.

467 Although some available resources (e.g. Dictyota and turf) were present in both conditions (WSE 468 and USE), measuring the contribution of algae to the sea urchin tissues can display key 469 information about how consumers assimilate habitat resources and this could reveal information 470 on the degree of disturbance (Layman et al., 2007b). Therefore, it is possible that the ecological 471 role of $D$. antillarum was different in each site and could be explained by the variation in the 472 number of available resources and a differential assimilation (Table 3). The higher $\delta^{15} \mathrm{~N}$ values

473 USE in the muscle of $D$. antillarum were a result of the synergistic effect determined by resource 474 availability and disturbance condition.

475 Pelagic sources may provide new sources of food and the possible nitrogen fixation carried out 476 by turf attached to pelagic Sargassum undoubtedly brought a new source of organic matter to 477 basal trophic levels (Rooker et al. 2006). However, those sources were not major contributors for 478 D. antillarum and appear to avoid the invasive pelagic macroalgae. This is consistent with the 479 feeding ecology by marine generalist herbivores (Boudouresque \& Verlaque, 2001) and such 480 feeding response is in line with evidence from other sea urchin species in the face of other 481 invasive resources. The experiments carried out by Tomas et al. (2011) provide evidence that 482 some seaweed invaders were strongly avoided by Paracentrotus lividus and therefore escape 483 enemy control by reducing herbivore preference.

484

485 The trophic level metric is very useful because the classical discrete trophic level definitions 486 ignore the value of food web connections, omnivory, and diet changes (Polis \& Strong, 1996; 
487 Vanderklift, Kendrick \& Smit, 2006). Generally the sea urchin D. antillarum has been 488 considered as a generalist herbivore (Ogden \& Lobel, 1978; Sammarco, 1980; Solandt \& 489 Campbell, 2001; Weil, Torres \& Ashton, 2005). Morillo-Velarde et al. (2018) found that for the 490 North of Quintana Roo Mexico D. antillarum occupied an herbivorous trophic position. 491 However, invertebrate samples have been found in the stomach contents this species in the 492 Caribbean, suggesting omnivorous behaviour (Rotjan \& Lewis, 2008; Rodríguez-Barreras et al., $4932015,2016)$.

494

495 The mean trophic level for $D$. antillarum exhibited at Mahahual was $2.35 \pm 0.18 \mathrm{WSE}$ up to $4963.08 \pm 0.13$ USE. Hence, WSE supported the idea that this species occupies an herbivorous 497 position. However USE D. antillarum revealed that the species can occupy different trophic 498 niches when faced with resource limitation. Under Sargassum blooms, D. antillarum displayed a 499 position more in line with omnivorous conditions, suggesting trophic level indicative of 500 herbivorous behaviour tending towards omnivory, according to Vander Zanden \& Rasmussen 501 (1999). These authors stated that primary consumers have a trophic position of 2.0 (strictly 502 herbivorous); but if organisms assimilate primary consumers, they are considered to be a trophic 503 level of 3.0. The results for Mahahual are consistent with Andrew (1989) who argued that sea 504 urchins could take advantage of ecosystem changes through omnivory if variation exists in the 505 availability of resources. Our results suggest that $D$. antillarum behave as a facultative omnivore 506 depending on patterns of nutrient availability. $\delta^{15} \mathrm{~N}$ signatures for D. antillarum in Mahahual 507 suggest a different carbon source USE. These signatures are also likely the result of 508 anthropogenic nitrogen inputs, as this site has a high eutrophication, being an area with elevated 509 touristic demand (Martínez-Rendis et al., 2016; Arias-González et al., 2017). Furthermore, 510 possible nitrogen fixation by anaerobic bacteria as an important factor in the variation of 511 available sources of food.

512

513 Regarding the TL values exhibited for $D$. antillarum in Mahahual USE $3.08 \pm 0.13$ versus $5142.35 \pm 0.18$ for WSE would place D. antillarum in an omnivorous position tending towards 515 carnivory. Similar values were obtained from Mediterranean sea urchins as a strategy to avoid 516 exclusion by sympatric species (Wagensteen et al. 2011). However, we cannot state that $D$. 517 antillarum is carnivorous in Mahahual. This would require a more complete temporal study, and 
518 an adjustment of a new $\delta^{15} \mathrm{~N}$ baseline for primary producers, considering that ${ }^{15} \mathrm{~N} /{ }^{14} \mathrm{~N}$ ratios can

519 vary spatially and temporally (Jennings et al. 1997; Vanderklift, Kendrick \& Smit, 2006).

520

521 The results for Xahuayxol showed also a trend towards higher $\delta^{15} \mathrm{~N}$. However by analyzing the 522 condition of $D$. antillarum in Xahuayxol no significant differences were observed. We can 523 assume that this locality was least changed in its foraging behavior position against the nutrients 524 modification and the species occupied a lower trophic level WSE. Meanwhile, Xcalak displayed 525 the opposite trend compared to Mahahual and Xahuayxol and USE D. antillarum trophic level 526 was lower than WSE. Our results suggest that for Xcalak the effect of Sargassum blooms 527 completely modified and reduced the possibility for finding available resources, displaying a 528 trophic level around 2.5 between the two scenarios of Sargassum blooms. This corresponds to a 529 predominantly herbivorous to omnivorous condition. Moreover this was confirmed with the 530 isotopic niche breadth data where a reduced niche was observed for Xcalak (Fig. 3).

531

532 The rank found for D. antillarum in this study is consistent with the study conducted by 533 Rodríguez-Barreras et al. (2015) in Puerto Rico where microinvertebrates were used as source of 534 organic matter by the sea urchin. Finally, TL values support the premise that echinoids are able 535 to modify their foraging behaviour depending on the availability of resources (Randall, 536 Schroeder \& Starck, 1964; Muthiga \& McClanahan, 2007), and in this case under Sargassum 537 blooms condition was not only determined by macroalgae availability, but for unusual conditions 538 that caused a shift in the ecosystem (Cabanillas-Terán et al., 2016).

539

\section{Isotopic niche breadth}

541 The ellipses provide integrated information on the relationship between the availability of 542 sources and the niche width. The results of Mahahual indicated that in USE. D. antillarum 543 consumes different carbon and nitrogen sources (Fig.4).

544 Several studies (Lawrence, 1975; Carpenter, 1981; Sammarco, 1982; Hay \& Fenical, 1988) 545 noted that echinoids have the ability to adapt their foraging behavior depending on algae 546 availability as well as their population density and site characteristics (Bak, Carpay \& de Ruyter 547 van Steveninck, 1984; Bak, 1994; Alvarado et al., 2016). We observed at Mahahual that USE D. 548 antillarum exhibited a broader trophic niche than WSE. Despite the limited resources this could 
549 lead to trophic overlap and stronger habitat degradation. SIAR results showed a resource shift 550 and this could be explained in terms of omnivory as stated by France et al. (1998) "omnivory is a 551 prevalent attribute of aquatic food webs".

552

553 The trophic niche of Xahuayxol reflects that there was no difference in the use of carbon and 554 nitrogen sources. It is noteworthy that for the case of Xcalak, the resulting isotopic niche of $D$. 555 antillarum was significantly smaller under Sargassum effect. This is consistent with the metric 556 that associates smaller niche amplitude with disturbed ecosystems (Layman et al., 2007b).

557

558 Limitations of the study

559 To assess the effect of differential management of Sargassum and to effectively evaluate the 560 effect of disposal management, quantitative information on beach disposal would be necessary.

561 From our results, it is clear that algae communities were modified due to Sargassum. However, 562 due to the structuring role of sea urchins, and, considering that algae respond to temporal 563 variability naturally, it would be necessary to study changing gradients at different time scales. 564 Such a temporal study would provide more conclusive information about the effect of Sargassum 565 spp. on benthic communities.

566 It is necessary to strengthen the sampling effort to evaluate current population status. A more 567 comprehensive discussion would need to include the interactions with other 568 herbivorous/omnivorous species, that coexist at each site and whether, or how they carry out 569 resource partitioning.

570 The metrics used in this study allowed us to evaluate the variation of the isotopic signatures that

571 formed the trophic spectrum of $D$. antillarum under two different scenarios. Metric values based 572 on an instantaneous characterization of a single food web provide a limited view of the food 573 web. Therefore, to evaluate the trophic structure and consequently its functional structure, the 574 most promising evaluations would have to include a comparison of multiple gradients, and, to 575 examine the same food web on a longer temporal perspective.

576 The deposited biomass regarding to $S$. fluitans and S. natans did not include a measurement of 577 the total arrived Sargassum blooms. However, our results established a baseline for the amounts 578 that were more available for the echinoids that inhabit the back section of the Caribbean shallow 579 reefs. 
580 It would be challenging to evaluate the ecological role of other coexisting species (Echinometra 581 viridis, E. lucunter and Eucidaris tribuloides), and to include samples of micro-invertebrates. 582 However, this could offer new clues to the connectivity between sympatric species, including 583 trophic loops and successional states of algal communities (Camus, Daroch \& Opazo, 2008) 584 within the benthic communities of coral reefs.

585

586

\section{Conclusions}

588 The present study provides an initial review of how trophic parameters of $D$. antillarum were 589 modified by the impact of pelagic Sargassum blooms in the Mexican Caribbean. The results 590 indicated that the effects of the leachates generated by the decomposition process, the input of 591 organic material and deposition in its vegetal structures modify the organic matter in the 592 environment and hence the isotopic signatures. This has negative consequences in the benthic 593 trophic structure, limiting the natural herbivory of $D$. antillarum. The source of available carbon 594 and nitrogen was modified, and the isotopic signatures of macroalgae associated with the reef 595 sites exhibited significantly lower values of $\delta^{15} \mathrm{~N}$. Consequently, the trophic niches were changed 596 and in the case of Xcalak, significantly reduced.

598 Acknowledgements

599 We acknowledge Katie Cramer, Gerald Islebe and two anonymous reviewers for their valuable 600 and helpful comments on the manuscript. We thank Comisión Nacional de Áreas Naturales 601 Protegidas (CONANP) for logistic support and Alberto de Jesus-Navarrete for lending the multi602 parameter water quality checker and. The first author is grateful to María Alfaro-Padilla, Roberto 603 Herrera-Pavón and James Boon for their logistic help during fieldwork and laboratory work, to 604 Alejandro Aragón for his help in editing Figure 1 and helping to modify Figure 2, and Rebecca 605 Friedel is acknowledged for improving the English of the manuscript.

606

\section{References}


608Alvarado JJ, Cortés J, Guzman H, Reyes-Bonilla H. 2016. Bioerosion by the sea urchin Diadema 609 mexicanum along Eastern Tropical Pacific coral reefs. Marine Ecology 37:1088-1102. DOI: $61010.1111 /$ maec. 12372.

611Alvarez-Filip L, Gill JA, Dulvy NK, Perry AL, Watkinson AR, Côté IM. 2011. Drivers of region612 wide declines in architectural complexity on Caribbean reefs. Coral Reefs 30:1051.

613Andrew NL. 1989. Contrasting ecological implications of food limitation in sea urchins and 614 herbivorous gastropods. Marine Ecology Progress Series 51:189-193.

615Arellano-Verdejo J, Lazcano-Hernandez HE, Cabanillas-Terán N. 2019. ERISNet: deep neural 616 network for Sargassum detection along the coastline of the Mexican Caribbean. PeerJ 7:e6842.

617Arias-González JE, Fung T, Seymour RM, Garza-Pérez JR, Acosta-González G, Bozec Y-M, 618 Johnson CR. 2017. A coral-algal phase shift in Mesoamerica not driven by changes in 619 herbivorous fish abundance. PloS One 12:e0174855.

620Aronson RB, Precht WF. 2006. Conservation, precaution, and Caribbean reefs. Coral Reefs 25:441621 450. DOI: 10.1007/s00338-006-0122-9.

622Bak RPM, Carpay M, de Ruyter van Steveninck ED. 1984. Densities of the sea urchin Diadema 623 antillarum before and after mass mortalities on the coral reefs of Curacao. Marine Ecology 624 Progress Series:105-108.

625Bak RPM. 1994. Sea urchin bioerosion on coral reefs: place in the carbonate budget and relevant 626 variables. Coral Reefs 13:99-103. DOI: 10.1007/BF00300768.

627Bauman AG, Burt JA, Feary DA, Marquis E, Usseglio P. 2010. Tropical harmful algal blooms: an 628 emerging threat to coral reef communities? Marine Pollution Bulletin 60:2117-2122. DOI:

629 10.1016/j.marpolbul.2010.08.015.

630Bearhop S, Adams CE, Waldron S, Fuller RA, MacLeod H. 2004. Determining trophic niche width: 631 a novel approach using stable isotope analysis. The Journal of Animal Ecology 73:1007-1012.

632Behmer ST, Joern A. 2008. Coexisting generalist herbivores occupy unique nutritional feeding 633 niches. Proceedings of the National Academy of Sciences of the United States of America 634 105:1977-1982. DOI: 10.1073/pnas.0711870105.

635Ben-David M, Schell DM. 2001. Mixing models in analyses of diet using multiple stable isotopes: a 636 response. Oecologia 127:180-184. DOI: 10.1007/s004420000570.

637Boecklen WJ, Yarnes CT, Cook BA, James AC. 2011. On the Use of Stable Isotopes in Trophic 638 Ecology. Annual Review of Ecology, Evolution, and Systematics 42:411-440. DOI:

639 10.1146/annurev-ecolsys-102209-144726.

640Boudouresque CF, Verlaque M. 2001. Ecology of Paracentrotus lividus. Developments in 641 Aquaculture and Fisheries Science 32:177-216.

642Box GEP, Cox DR. 1964. An Analysis of Transformations. Journal of the Royal Statistical Society. 643 Series B, Statistical Methodology 26:211-243. 
644Cabanillas-Terán N, Loor-Andrade P, Rodríguez-Barreras R, Cortés J. 2016. Trophic ecology of sea 645 urchins in coral-rocky reef systems, Ecuador. PeerJ 4:e1578. DOI: 10.7717/peerj.1578.

646Camacho-Cruz KA, Ortiz-Hernández MC, Sánchez A, Carrillo L, De Jesús Navarrete A. 2019. 647 Water quality in the eastern karst region of the Yucatan Peninsula: nutrients and stable nitrogen 648 isotopes in turtle grass, Thalassia testudinum. Environmental Science and Pollution Research 649 International. DOI: 10.1007/s11356-019-04757-3.

650Camus PA, Daroch K, Opazo LF. 2008. Potential for omnivory and apparent intraguild predation in 651 rocky intertidal herbivore assemblages from northern Chile. Marine Ecology Progress Series $652361: 35-45$.

653Carpenter EJ, Cox JL. 1974. Production of pelagic Sargassum and a blue-green epiphyte in the 654 western Sargasso Sea. Limnology and Oceanography 19:429-436.

655Carpenter RC. 1981. Grazing by Diadema antillarum (Philippi) and its effects on the benthic algal 656 community. Journal of Marine Research 39:749-765.

657Carpenter RC. 1986. Partitioning herbivory and its effects on coral reef algal communities. 658 Ecological Monographs 56:345-364.

659Colombini I, Chelazzi L. 2003. Influence of marine allochthonous input on sandy beach 660 communities. Oceanography and Marine Biology: An Annual Review 41:115-159.

661Cramer KL, Jackson JBC, Angioletti CV, Leonard-Pingel J, Guilderson TP. 2012. Anthropogenic 662 mortality on coral reefs in Caribbean Panama predates coral disease and bleaching. Ecology 663 Letters 15:561-567.

664Cuevas E, Uribe-Martínez A, Liceaga-Correa M de LÁ. 2018. A satellite remote-sensing multi665 index approach to discriminate pelagic Sargassum in the waters of the Yucatan Peninsula, 666 Mexico. International Journal of Remote Sensing 39:3608-3627. DOI:

$66710.1080 / 01431161.2018 .1447162$.

668De Széchy MTM, Guedes PM, Baeta-Neves MH, Oliveira EN. 2012. Verification of Sargassum 669 natans (Linnaeus) Gaillon (Heterokontophyta: Phaeophyceae) from the Sargasso Sea off the 670 coast of Brazil, western Atlantic Ocean. Check list 8:638-641. DOI: 10.15560/8.4.638.

671DeNiro MJ, Epstein S. 1981. Influence of diet on the distribution of nitrogen isotopes in animals. 672 Geochimica et cosmochimica acta 45:341-351. DOI: 10.1016/0016-7037(81)90244-1.

673Dorado S, Rooker JR, Wissel B, Quigg A. 2012. Isotope baseline shifts in pelagic food webs of the 674 Gulf of Mexico. Marine Ecology Progress Series 464:37-49.

675Eklöf JS, de la Torre-Castro M, Gullström M, Uku J, Muthiga N, Lyimo T, Bandeira SO. 2008. Sea 676 urchin overgrazing of seagrasses: A review of current knowledge on causes, consequences, and 677 management. Estuarine, Coastal and Shelf Science 79:569-580. DOI:

678 10.1016/j.ecss.2008.05.005.

679Ferreira CEL, de Oliveira Ribeiro Junqueira A, Villac MC, Lopes RM. 2009. Marine Bioinvasions 680 in the Brazilian Coast: Brief Report on History of Events, Vectors, Ecology, Impacts and 
681 Management of Non-indigenous Species. In: Rilov G, Crooks JA eds. Biological Invasions in 682 Marine Ecosystems: Ecological, Management, and Geographic Perspectives. Berlin, Heidelberg: 683 Springer Berlin Heidelberg, 459-477. DOI: 10.1007/978-3-540-79236-9_27.

684France R, Chandler M, Peters R. 1998. Mapping trophic continua of benthic foodwebs: body size- $\delta$ 68515 N relationships. Marine Ecology Progress Series 174:301-306.

686France R, Holmquist J, Chandler M, Cattaneo A. 1998. $\delta 15 \mathrm{~N}$ evidence for nitrogen fixation 687 associated with macroalgae from a seagrass-mangrove-coral reef system. Marine Ecology 688 Progress Series 167:297-299. DOI: 10.3354/meps167297.

689France RL. 1995. Differentiation between littoral and pelagic food webs in lakes using stable 690 carbon isotopes. Limnology and Oceanography 40:1310-1313. DOI: 10.4319/1o.1995.40.7.1310.

691Franks JS, Johnson DR, Ko DS. 2016. Pelagic Sargassum in the tropical North Atlantic. Gulf and 692 Caribbean Research 27:SC6-SC11.

693Fry B, Sherr EB. 1984. $\delta 13 \mathrm{C}$ measurements as indicators of carbon flow in marine and freshwater 694 ecosystems, Contributions to Marine Science 27, 13-47.

695Fry B, Sherr EB. 1989. $813 \mathrm{C}$ Measurements as Indicators of Carbon Flow in Marine and 696 Freshwater Ecosystems. In: Rundel P.W., Ehleringer J.R., Nagy K.A. ed. Stable Isotopes in 697 Ecological Research. New York: Springer, 196-229. DOI: 10.1007/978-1-4612-3498-2_12.

698Fry B. 2006. Stable Isotope Ecology. New York: Springer. DOI: 10.1007/0-387-33745-8.

699Gower J, Young E, King S. 2013. Satellite images suggest a new Sargassum source region in 2011. 700 Remote Sensing Letters 4:764-773. DOI: 10.1080/2150704X.2013.796433.

701Haas AF, Jantzen C, Naumann MS, Iglesias-Prieto R, Wild C. 2010. Organic matter release by the 702 dominant primary producers in a Caribbean reef lagoon: implication for in situ $\mathrm{O} 2$ availability. 703 Marine Ecology Progress Series 409:27-39. DOI: 10.3354/meps08631.

704Hamaoka H, Okuda N, Fukumoto T, Miyasaka H, Omori K. 2010. Seasonal dynamics of a coastal 705 food web: stable isotope analysis of a higher consumer. In: Ohkouchi, N., Tayasu, I., Koba, K. 706 ed. Earth, life, and isotopes. Kyoto University Press, 161-181.

707Hay ME, Fenical W. 1988. Marine Plant-Herbivore Interactions: The Ecology of Chemical 708 Defense. Annual Review of Ecology and Systematics 19:111-145. DOI:

709 10.1146/annurev.es.19.110188.000551.

710Hobson KA, Welch HE. 1992. Determination of trophic relationships within a high Arctic marine 711 food web using $\delta 13 \mathrm{C}$ and $\delta 15 \mathrm{~N}$ analysis. Marine Ecology Progress Series 84:9-18.

712Hobson KA. 1999. Tracing origins and migration of wildlife using stable isotopes: a review. 713 Oecologia 120:314-326. DOI: 10.1007/s004420050865.

714Hoffman DM. 2009. Institutional Legitimacy and Co-Management of a Marine Protected Area: 715 Implementation Lessons from the Case of Xcalak Reefs National Park, Mexico. Human 716 organization 68:39-54. 
717Hughes TP. 1994. Catastrophes, phase shifts, and large-scale degradation of a Caribbean coral reef. 718 Science 265:1547-1551. DOI: 10.1126/science.265.5178.1547.

719Hunter MD, Price PW. 1992. Playing chutes and ladders: heterogeneity and the relative roles of 720 bottom-up and top-down forces in natural communities. Ecology 73:724-732.

721Jackson AL, Inger R, Parnell AC, Bearhop S. 2011. Comparing isotopic niche widths among and 722 within communities: SIBER--Stable Isotope Bayesian Ellipses in R. The Journal of Animal 723 Ecology 80:595-602.

724Jennings S, Reñones O, Morales-Nin B, Polunin NV, Moranta J, Coll J. (1997). Spatial variation in 725 the $15 \mathrm{~N}$ and $13 \mathrm{C}$ stable isotope composition of plants, invertebrates and fishes on Mediterranean 726 reefs: implications for the study of trophic pathways. Marine Ecology Progress Series 146:109-

727116.

728Johnson DR, Ko DS, Franks JS, Moreno P, Sanchez-Rubio G. 2013. The Sargassum Invasion of the 729 Eastern Caribbean and Dynamics of the Equatorial North Atlantic Invasión de Sargazo en el 730 Caribe Oriental y la Dinámica en la Zona Ecuatorial del Atlántico Norte L'Invasion de Sargasse 731 dans les Caraïbes Orientales et leur Dynamique dans la. In: Proceedings of the 65th Gulf and

732 Caribbean Fisheries Institute. 102-103.

733Jordán-Garza AG, Maldonado MA, Baker DM, Rodríguez-Martínez RE. 2008. High abundance of 734 Diadema antillarum on a Mexican reef. Coral Reefs 27:295-295.

735Jorgensen P, Espinoza-Ávalos J, Bahena-Basave H. 2008. High population density survival of the 736 sea urchin Diadema antillarum (Philippi 1845) to a category 5 hurricane in southern Mexican 737 Caribbean. Hidrobiológica 18.

738Kendrick GA, Hegge BJ, Wyllie A, Davidson A, Lord DA. 2000. Changes in Seagrass Cover on 739 Success and Parmelia Banks, Western Australia Between 1965 and 1995. Estuarine, Coastal and 740 Shelf Science 50:341-353. DOI: 10.1006/ecss.1999.0569.

741Kissling DL, Precht WF, Miller SL, Chiappone M. 2014. Historical reconstruction of population 742 density of the echinoid Diadema antillarum on Florida Keys shallow bank-barrier reefs. Bulletin 743 of Marine Science 90:665-679.

744Lapointe BE, Barile PJ, Littler MM, Littler DS. 2005. Macroalgal blooms on southeast Florida coral 745 reefs: II. Cross-shelf discrimination of nitrogen sources indicates widespread assimilation of 746 sewage nitrogen. Harmful Algae 4:1106-1122. DOI: 10.1016/j.hal.2005.06.002.

747Lapointe BE, Langton R, Bedford BJ, Potts AC, Day O, Hu C. 2010. Land-based nutrient 748 enrichment of the Buccoo Reef Complex and fringing coral reefs of Tobago, West Indies.

749 Marine Pollution Bulletin 60:334-343. DOI: 10.1016/j.marpolbul.2009.10.020.

750Lapointe BE, Thacker K, Hanson C, Getten L. 2011. Sewage pollution in Negril, Jamaica: effects 751 on nutrition and ecology of coral reef macroalgae. Chinese Journal of Oceanology and 752 Limnology 29:775-789. DOI: 10.1007/s00343-011-0506-8.

753Lawrence JM. 1975. On the relationships between marine plants and sea urchins. Oceanography 754 and Marine Biology: An Annual Review 13:213-286. 
755Layman CA, Araujo MS, Boucek R, Hammerschlag-Peyer CM, Harrison E, Jud ZR, Matich P, 756 Rosenblatt AE, Vaudo JJ, Yeager LA, Others. 2012. Applying stable isotopes to examine food757 web structure: an overview of analytical tools. Biological reviews of the Cambridge

758 Philosophical Society 87:545-562.

759Layman CA, Arrington DA, Montaña CG, Post DM. 2007a. Can stable isotope ratios provide for 760 community-wide measures of trophic structure? Ecology 88:42-48.

761Layman CA, Quattrochi JP, Peyer CM, Allgeier JE. 2007b. Niche width collapse in a resilient top 762 predator following ecosystem fragmentation. Ecology letters 10:937-944. DOI: 10.1111/j.1461763 0248.2007.01087.x.

764Lessios HA, Cubit JD, Robertson DR, Shulman MJ, Parker MR, Garrity SD, Levings SC. 1984. 765 Mass mortality of Diadema antillarum on the Caribbean coast of Panama. Coral Reefs 3:173766182.

767Littler DS, Littler MM. 2000. Caribbean reef plants. Washington, DC. : OffShore Graphics.

768Louime C, Fortune J, Gervais G. 2017. Sargassum Invasion of Coastal Environments: A Growing 769 Concern. American Journal of Environmental Sciences 13:58-64. DOI:

$770 \quad$ 10.3844/ajessp.2017.58.64.

771Maldonado-Sánchez J, Mariño-Tapia I, Teresa Herrera-Dorantes M, Ardisson P-L. 2019. 772 Hydrodynamic conditions that favor the settlement of Diadema antillarum to a western 773 Caribbean coral reef. Bulletin of Marine Science 95:251-264.

774Maldonado-Sánchez MA. 2018. Influencia ecológica del erizo de mar Diadema antillarum (Philippi, 775 1845) sobre la estructuración de la comunidad bentónica de la laguna arrecifal de Xcalak,

776 Quintana Roo. PhD thesis, Centro de Investigación y de Estudios avanzados del Instituto

777 Politécnico Nacional Unidad Mérida.

778Mariño-Tapia I, Silva R, Enriquez C, Mendoza-Baldwin E, Escalante-Mancera E, Ruiz-Rentería F. 779 2011. Wave transformation and wave-driven circulation on natural reefs under extreme hurricane 780 conditions. Coastal Engineering Proceedings 1:28.

781Martínez-Rendis M, Acosta-González G, Hernández-Stefanoni JL, Arias González JE. 2016. 782 Quantifying the reefscape transformation of a coastal Caribbean coral reef during a phase shift 783 and the associated coastal landscape change. Marine Ecology 37:697-710. DOI:

$784 \quad 10.1111 /$ maec. 12334.

785Minagawa M, Wada E. 1984. Stepwise enrichment of $15 \mathrm{~N}$ along food chains: Further evidence and 786 the relation between $\delta 15 \mathrm{~N}$ and animal age. Geochimica et cosmochimica acta 48:1135-1140.

787 DOI: 10.1016/0016-7037(84)90204-7.

788Montoya JP, Carpenter EJ, Capone DG. 2002. Nitrogen fixation and nitrogen isotope abundances in 789 zooplankton of the oligotrophic North Atlantic. Limnology and oceanography 47:1617-1628.

790Moore JW, Semmens BX. 2008. Incorporating uncertainty and prior information into stable isotope 791 mixing models. Ecology letters 11:470-480. DOI: 10.1111/j.1461-0248.2008.01163.x. 
792Morillo-Velarde PS, Briones-Fourzán P, Álvarez-Filip L, Aguíñiga-García S, Sánchez-González A, 793 Lozano-Álvarez E. 2018. Habitat degradation alters trophic pathways but not food chain length 794 on shallow Caribbean coral reefs. Scientific reports 8:4109.

795Muthiga NA, McClanahan TR. 2007. Ecology of Diadema. In: Developments in Aquaculture and 796 Fisheries Science. Elsevier, 205-225.

797Newsome SD, Martinez del Rio C, Bearhop S, Phillips DL. 2007. A niche for isotopic ecology. 798 Frontiers in Ecology and the Environment 5:429-436. DOI: 10.1890/060150.1.

799Ogden JC, Lobel PS. 1978. The role of herbivorous fishes and urchins in coral reef communities. 800 Environmental Biology of Fishes 3:49-63. DOI: 10.1007/BF00006308.

8010wens NJP. 1987. Natural Variations in $15 \mathrm{~N}$ in the Marine Environment. In: Blaxter JHS, 802 Southward AJ eds. Advances in Marine Biology. Academic Press, 389-451. DOI:

803 10.1016/S0065-2881(08)60077-2.

804Oyesiku OO, Egunyomi A. 2014. Identification and chemical studies of pelagic masses of 805 Sargassum natans (Linnaeus) Gaillon and S. fluitans (Borgessen) Borgesen (brown algae), found 806 offshore in Ondo State, Nigeria. African Journal of Biotechnology 13:1188-1193.

807Parnell A, Jackson A. 2013. siar: Stable Isotope Analysis in R. R package version 4.2. Available 808 from: Available from: http://CRAN. R-project. org/package= siar. (23 March 2014). [Links].

809Parnell AC, Inger R, Bearhop S, Jackson AL. 2010. Source partitioning using stable isotopes: 810 coping with too much variation. PloS One 5:e9672. DOI: 10.1371/journal.pone.0009672.

811Peterson BJ, Fry B. 1987. Stable Isotopes in Ecosystem Studies. Annual Review of Ecology and 812 Systematics 18:293-320.

813Peterson BJ. 1999. Stable isotopes as tracers of organic matter input and transfer in benthic food 814 webs: A review. Acta Oecologica 20:479-487. DOI: 10.1016/S1146-609X(99)00120-4.

815Phillips DL, Gregg JW. 2003. Source partitioning using stable isotopes: coping with too many 816 sources. Oecologia 136:261-269. DOI: 10.1007/s00442-003-1218-3.

817Phillips DL, Inger R, Bearhop S, Jackson AL, Moore JW, Parnell AC, Semmens BX, Ward EJ. 818 2014. Best practices for use of stable isotope mixing models in food-web studies. Canadian 819 Journal of Zoology 92:823-835.

820Phillips DL, Koch PL. 2002. Incorporating concentration dependence in stable isotope mixing 821 models. Oecologia 130:114-125. DOI: 10.1007/s004420100786.

822Polis GA, Strong DR. 1996. Food Web Complexity and Community Dynamics. The American 823 Naturalist 147:813-846. DOI: 10.1086/285880.

824Polunin NVC, Morales-Nin B, Pawsey WE, Cartes JE, Pinnegar JK, Moranta J. 2001. Feeding 825 relationships in Mediterranean bathyal assemblages elucidated by stable nitrogen and carbon 826 isotope data. Marine Ecology Progress Series 220:13-23. 
827Post DM, Layman CA, Arrington DA, Takimoto G, Quattrochi J, Montaña CG. 2007. Getting to the 828 fat of the matter: models, methods and assumptions for dealing with lipids in stable isotope 829 analyses. Oecologia 152:179-189. DOI: 10.1007/s00442-006-0630-x.

830Prado P, Alcoverro T, Romero J. 2010. Influence of nutrients in the feeding ecology of seagrass 831 (Posidonia oceanica L.) consumers: a stable isotopes approach. Marine Biology 157:715-724. 832 DOI: 10.1007/s00227-009-1355-2.

833Randall JE, Schroeder RE, Starck WA. 1964. Notes on the biology of the echinoid Diadema 834 antillarum. Caribbean Journal of Science 4:421-433.

835Risk MJ, Lapointe BE, Sherwood OA, Bedford BJ. 2009. The use of $\delta 15 \mathrm{~N}$ in assessing sewage 836 stress on coral reefs. Marine Pollution Bulletin 58:793-802. DOI:

837 10.1016/j.marpolbul.2009.02.008.

838Rodríguez SR. 2003. Consumption of drift kelp by intertidal populations of the sea urchin 839 Tetrapygus niger on the central Chilean coast: possible consequences at different ecological 840 levels. Marine Ecology Progress Series 251:141-151.

841Rodríguez-Barreras R, Cuevas E, Cabanillas-Terán N, Branoff B. 2016. Understanding trophic 842 relationships among Caribbean sea urchins. Revista de Biología Tropical 64:837-848.

843Rodríguez-Barreras R, Cuevas E, Cabanillas-Terán N, Sabat AM. 2015. Potential omnivory in the 844 sea urchin Diadema antillarum? Regional Studies in Marine Science 2:11-18. DOI:

845 10.1016/j.rsma.2015.08.005.

846Rodríguez-Martínez RE, Medina-Valmaseda AE, Blanchon P, Monroy-Velázquez LV, Almazán847 Becerril A, Delgado-Pech B, Vásquez-Yeomans L, Francisco V, García-Rivas MC. 2019. Faunal 848 mortality associated with massive beaching and decomposition of pelagic Sargassum. Marine 849 Pollution Bulletin 146:201-205.

850Rodríguez-Martínez RE, van Tussenbroek B, Jordán-Dahlgren E. 2016. Afluencia masiva de 851 sargazo pelágico a la costa del Caribe mexicano (2014-2015). Florecimientos Algales Nocivos en 852 México. Ensenada: CICESE:352-365.

853Rooker JR, Turner JP, Holt SA. 2006. Trophic ecology of Sargassum-associated fishes in the Gulf 854 of Mexico determined from stable isotopes and fatty acids. Marine Ecology Progress Series 855 313:249-259.

856Rotjan RD, Lewis SM. 2008. Impact of coral predators on tropical reefs. Marine Ecology Progress 857 Series 367:73-91.

858Sala E, Ribes M, Hereu B, Zabala M, Alvà V, Coma R, Garrabou J. 1998. Temporal variability in 859 abundance of the sea urchins Paracentrotus lividus and Arbacia lixula in the northwestern 860 Mediterranean: comparison between a marine reserve and an unprotected area. Marine Ecology 861 Progress Series 168:135-145.

862Sammarco PW. 1980. Diadema and its relationship to coral spat mortality: Grazing, competition, 863 and biological disturbance. Journal of Experimental Marine Biology and Ecology 45:245-272. 864 DOI: 10.1016/0022-0981(80)90061-1. 
865Sammarco PW. 1982. Echinoid grazing as a structuring force in coral communities: Whole reef 866 manipulations. Journal of Experimental Marine Biology and Ecology 61:31-55. DOI:

867 10.1016/0022-0981(82)90020-X.

868Schell JM, Goodwin DS, Siuda ANS. 2015. Recent Sargassum inundation events in the Caribbean: 869 Shipboard observations reveal dominance of a previously rare form. Oceanography 28:8-11.

870Schmitter-Soto JJ, Aguilar-Perera A, Cruz-Martínez A, Herrera-Pavón RL, Morales-Aranda AA, 871 Cobián-Rojas D. 2017. Interdecadal trends in composition, density, size, and mean trophic level 872 of fish species and guilds before and after coastal development in the Mexican Caribbean.

873 Biodiversity and Conservation:1-16. DOI: 10.1007/s10531-017-1446-1.

874Sissini MN, de Barros Barreto MBB, Széchy MTM, de Lucena MB, Oliveira MC, Gower J, Liu G, 875 de Oliveira Bastos E, Milstein D, Gusmão F, Martinelli-Filho JE, Alves-Lima C, Colepicolo P, 876 Ameka G, de Graft-Johnson K, Gouvea L, Torrano-Silva B, Nauer F, Marcos de Castro Nunes J, 877 Barufi JB, Rörig L, Riosmena-Rodríguez R, Mello TJ, Lotufo LVC, Horta PA. 2017. The 878 floating Sargassum (Phaeophyceae) of the South Atlantic Ocean - likely scenarios. Phycologia 879 56:321-328. DOI: $10.2216 / 16-92.1$.

880Smetacek V, Zingone A. 2013. Green and golden seaweed tides on the rise. Nature 504:84-88. 881 DOI: 10.1038/nature12860.

882Solandt JL, Campbell AC. 2001. Macroalgal feeding characteristics of the sea urchin Diadema 883 antillarum Philippi at Discovery Bay, Jamaica. Caribbean Journal of Science 37:227-238.

884Solarin BB, Bolaji DA, Fakayode OS, Akinnigbagbe RO. 2014. Impacts of an invasive seaweed 885 Sargassum hystrix var. fluitans (borgesen 1914) on the fisheries and other economic implications 886 for the nigerian coastal waters. IOSR Journal of Agriculture and Veterinary Science 7:1-6.

887Steneck RS, Lang JC. 2003. Mexico. Rapid Assessment of Mexico’s Yucatan Reef in 1997 and 888 1999: Pre-and Post-1998 Mass Bleaching and Hurricane Mitch (Stony Corals, Algae and Fishes). 889 Atoll research Bulletin.

890Sweatman JL, Layman CA, Fourqurean JW. 2017. Habitat fragmentation has some impacts on 891 aspects of ecosystem functioning in a sub-tropical seagrass bed. Marine Environmental Research 892 126:95-108. DOI: 10.1016/j.marenvres.2017.02.003.

893Tomas F, Alvarez-Cascos D, Turon X, Romero J. 2006. Differential element assimilation by sea 894 urchins Paracentrotus lividus in seagrass beds: implications for trophic interactions. Marine 895 Ecology Progress Series 306:125-131.

896Tomas F, Box A, Terrados J. 2011. Effects of invasive seaweeds on feeding preference and 897 performance of a keystone Mediterranean herbivore. Biological Invasions 13:1559-1570. DOI: 898 10.1007/s 10530-010-9913-6.

899Umezawa Y, Miyajima T, Yamamuro M, Kayanne H, Koike I. 2002. Fine-scale mapping of land900 derived nitrogen in coral reefs by $\delta 15 \mathrm{~N}$ in macroalgae. Limnology and Oceanography 47:14059011416. 
902van Tussenbroek BI, Hernández-Arana HA, Rodríguez-Martínez RE, Espinoza-Avalos J, Canizales903 Flores HM, González-Godoy CE, Barba-Santos MG, Vega-Zepeda A, Collado-Vides L. 2017.

904 Severe impacts of brown tides caused by Sargassum spp. on near-shore Caribbean seagrass

905 communities. Marine Pollution Bulletin 122:272-281. DOI: 10.1016/j.marpolbul.2017.06.057.

906Vander Zanden M, Rasmussen JB. 1999. Primary consumer $\delta 13 \mathrm{C}$ and $\delta 15 \mathrm{~N}$ and the trophic 907 position of aquatic consumers. Ecology 80:1395-1404.

908Vander Zanden M, Rasmussen JB. 2001. Variation in $\delta 15 \mathrm{~N}$ and $\delta 13 \mathrm{C}$ trophic fractionation: 909 implications for aquatic food web studies. Limnology and Oceanography 46:2061-2066.

910Vander Zanden MJ, Rasmussen JB. 1996. A Trophic Position Model of Pelagic Food Webs: Impact 911 on Contaminant Bioaccumulation in Lake Trout. Ecological monographs 66:451-477. DOI:

$912 \quad 10.2307 / 2963490$.

913Vanderklift MA, Kendrick GA, Smit AJ. 2006. Differences in trophic position among sympatric sea 914 urchin species. Estuarine, Coastal and Shelf Science 66:291-297. DOI:

915 10.1016/j.ecss.2005.09.004.

916Wang M, Hu C, Barnes BB, Mitchum G, Lapointe B, Montoya JP. 2019. The great Atlantic 917 Sargassum belt. Science 365:83-87.

918Wang M, Hu C, Cannizzaro J, English D, Han X, Naar D, Lapointe B, Brewton R, Hernandez F. 919 2018. Remote sensing of Sargassum biomass, nutrients, and pigments. Geophysical Research 920 Letters. DOI: 10.1029/2018GL078858.

921Weil E, Torres JL, Ashton M. 2005. Population characteristics of the sea urchin Diadema antillarum 922 in La Parguera, Puerto Rico, 17 years after the mass mortality event. Revista de Biologia 923 Tropical 53 Suppl 3:219-231.

924Wild C, Haas A, Naumann M, Mayr C, El-Zibdah M. 2010. Comparative investigation of organic 925 matter release by corals and benthic reef algae--implications for pelagic and benthic microbial 926 metabolism. Coral reefs in a time of change--case studies to understand potential 927 biogeochemical consequences of phase shifts from corals to benthic algae:121.

928Wing SR, McLeod RJ, Clark KL, Frew RD. 2008. Plasticity in the diet of two echinoderm species 929 across an ecotone: microbial recycling of forest litter and bottom-up forcing of population 930 structure. Marine Ecology Progress Series 360:115-123.

931Zar JH. 1999. Biostatistical analysis. India: Pearson Education.

932 


\section{Figure 1}

\section{Study sites}

Study area and sampling localities at the south coast of Quintana Roo: Mahahual (A), Xahuayxol (B) and Xcalak (C). The green polygon represents the marine protected area Parque Nacional Arrecifes de Xcalak (PNAX). Figure credit: Alejandro A. Aragón-Moreno

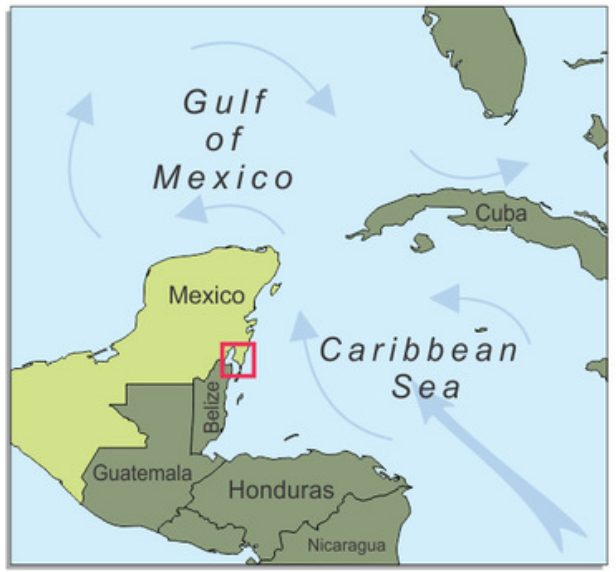

Sites

A Mahahual

B Xahuayxol

C Xcalak

Polygons

Parque Nacional Arrecifes de Xcalak (PNAX)

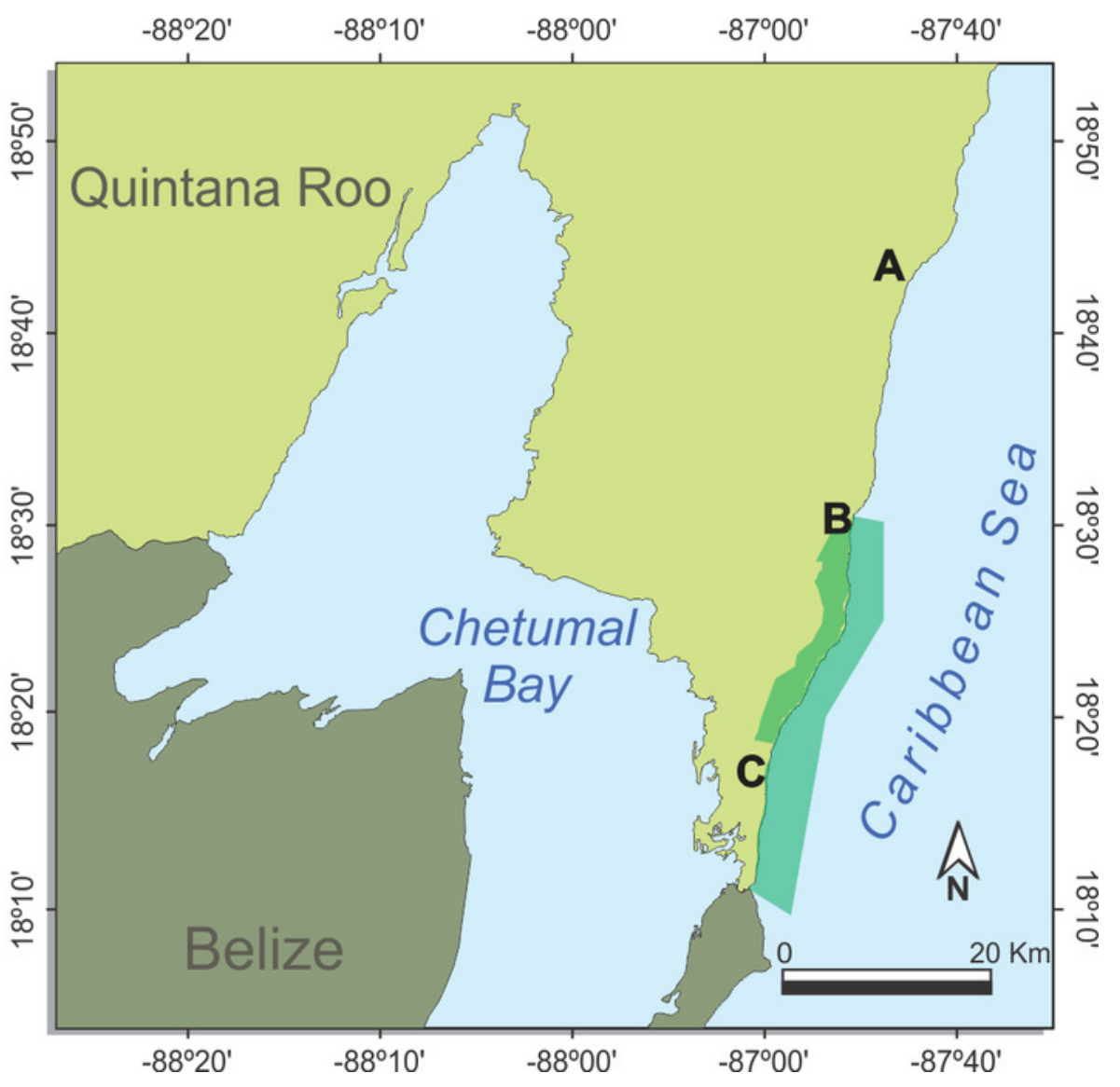




\section{Figure 2}

Lagoon reef-scape showing the sections with Sargassum blooms

Lagoon reef-scape showing the sections: a: decomposing Sargassum spp., Section b:

leachates (dark brown water) and section c: back reef, areas without visible leachates. Based on van Tussenbroek et al. 2017.

Coast line

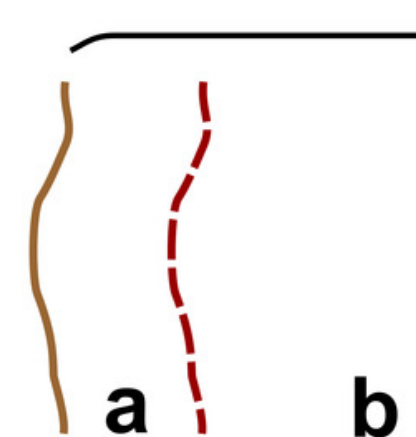

Reef lagoon

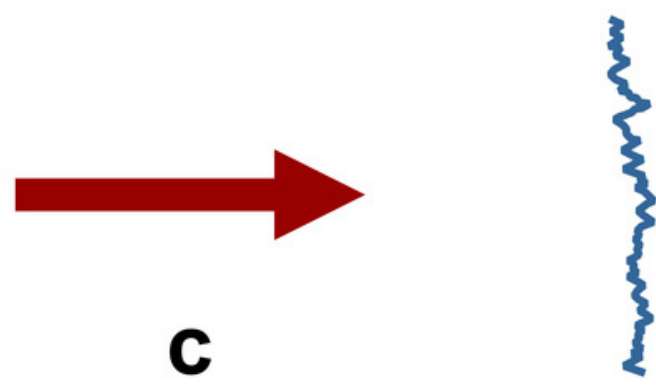

Reef crest 


\section{Figure 3}

Dissolved Oxygen values

Dissolved Oxygen $\left(\mathrm{mgl}^{-1}\right)$ values along the distance to shoreline at Mahahual (blue), Xahuayxol (purple) and Xcalak (green) considering the following sections: a: decomposing Sargassum spp., Section b: leachates (dark brown water) and section c: back reef, areas without visible leachates. 


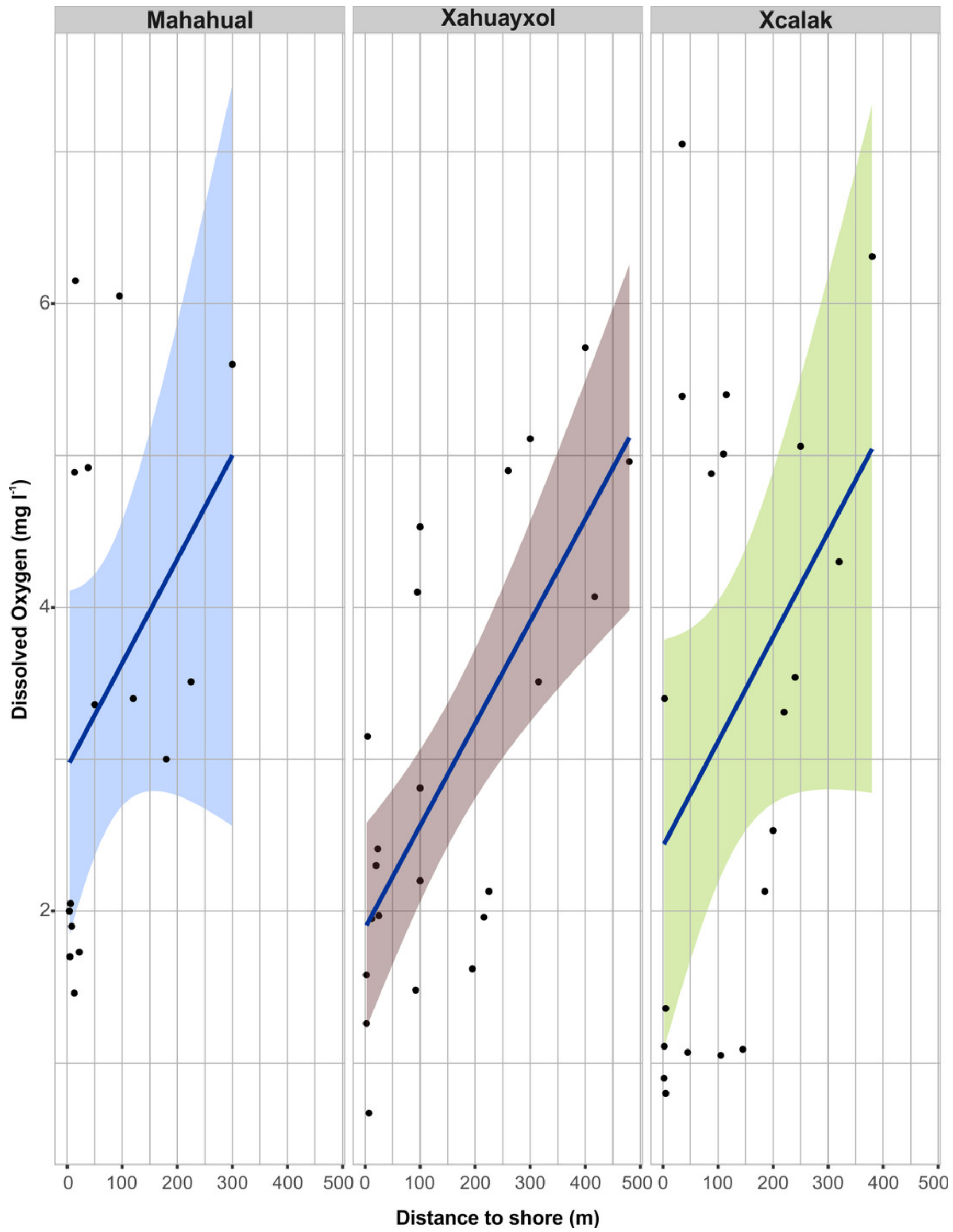




\section{Figure 4}

Algal resources proportions consumed by Diadema antillarum

Contribution rates of algae to the diet of Diadema antillarum in the two scenarios (WSE and USE). Results are shown as 25\% (light error bars),75\% (grey error bars) and 95\% (dark error bars) of credibility intervals. (A) Represents the contribution for $D$. antillarum at Mahahual without Sargassum effect (WSE), (B) represents D. antillarum at Mahahual under Sargassum effect (USE); (C) represents $D$. antillarum in Xahuayxol WSE, (D) represents $D$. antillarum in Xahuayxol USE; (E) represents $D$. antillarum in Xcalak WSE and (F) represents $D$. antillarum in Xcalak USE. Bloom turf is the Sargassum's associated turf. The blue bar represents the pelagic sources USE. 


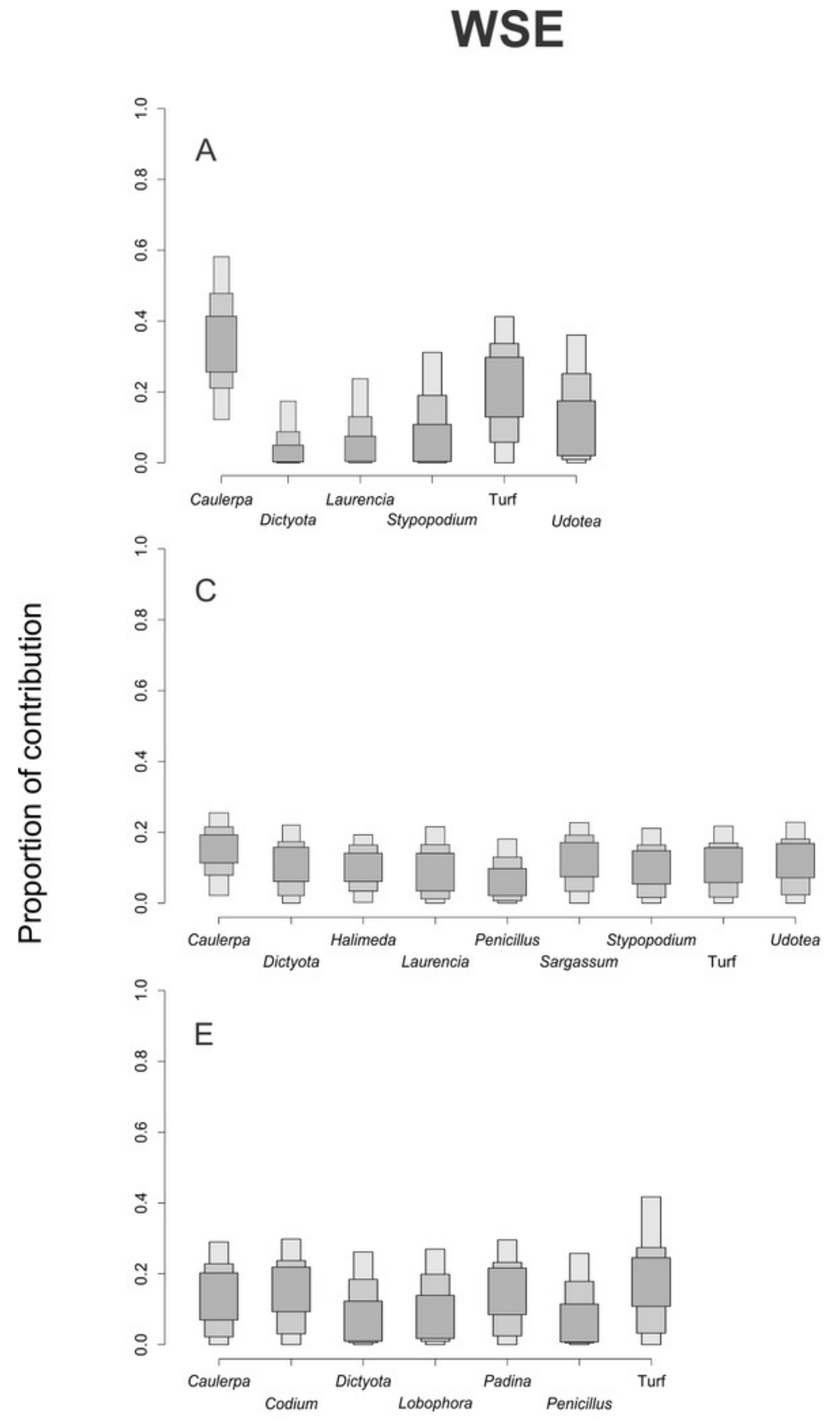

USE
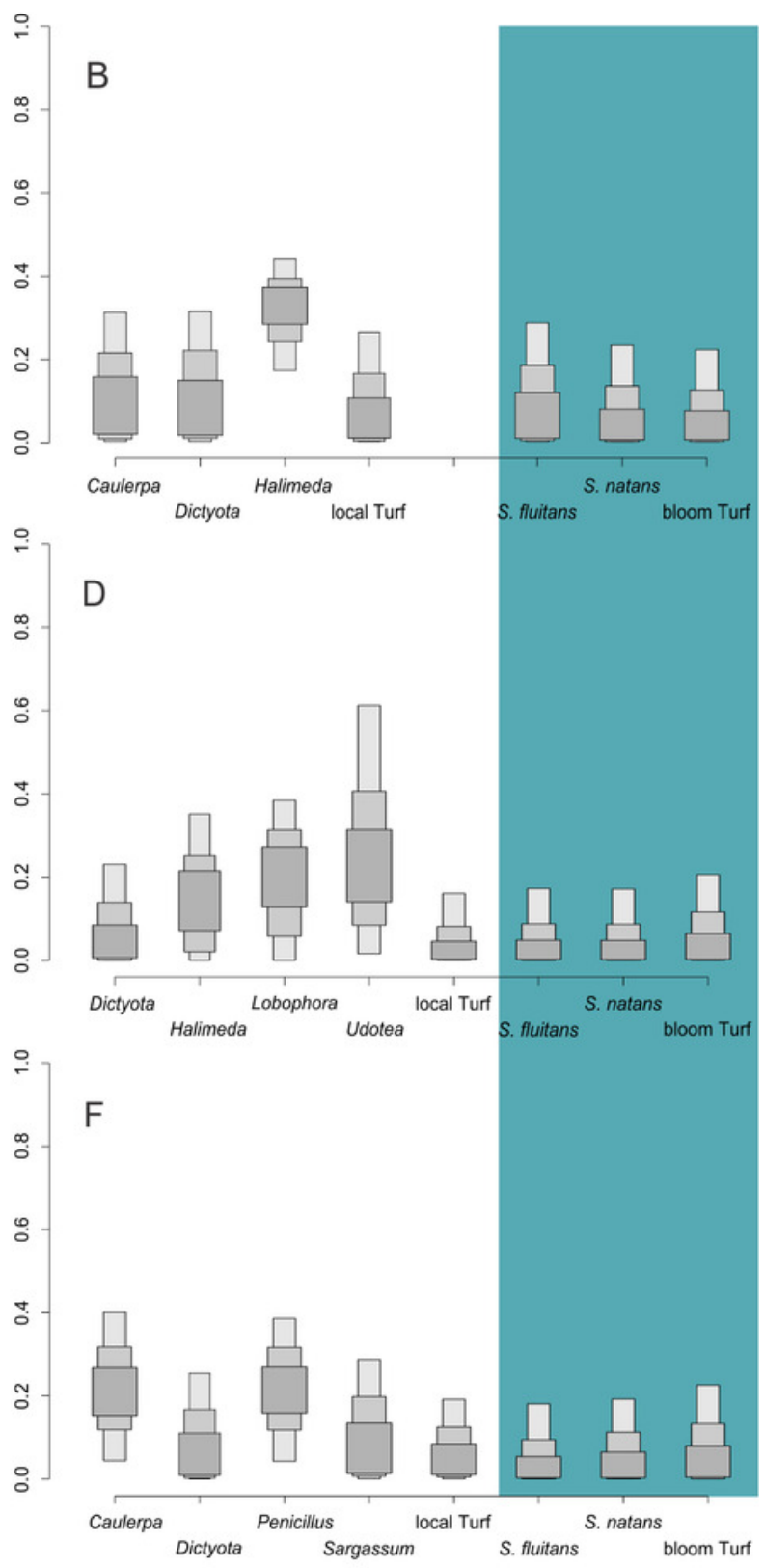

Source (algae) 
Figure $\mathbf{5}$ (on next page)

Isotope niche breadth of the sea urchin Diadema antillarum

Isotope niche breadth of the sea urchin Diadema antillarum at Mahahual (A), Xahuayxol (B) and Xcalak (C). Dotted lines are without Sargassum effect (WSE) and solid lines under Sargassum effect (USE). 

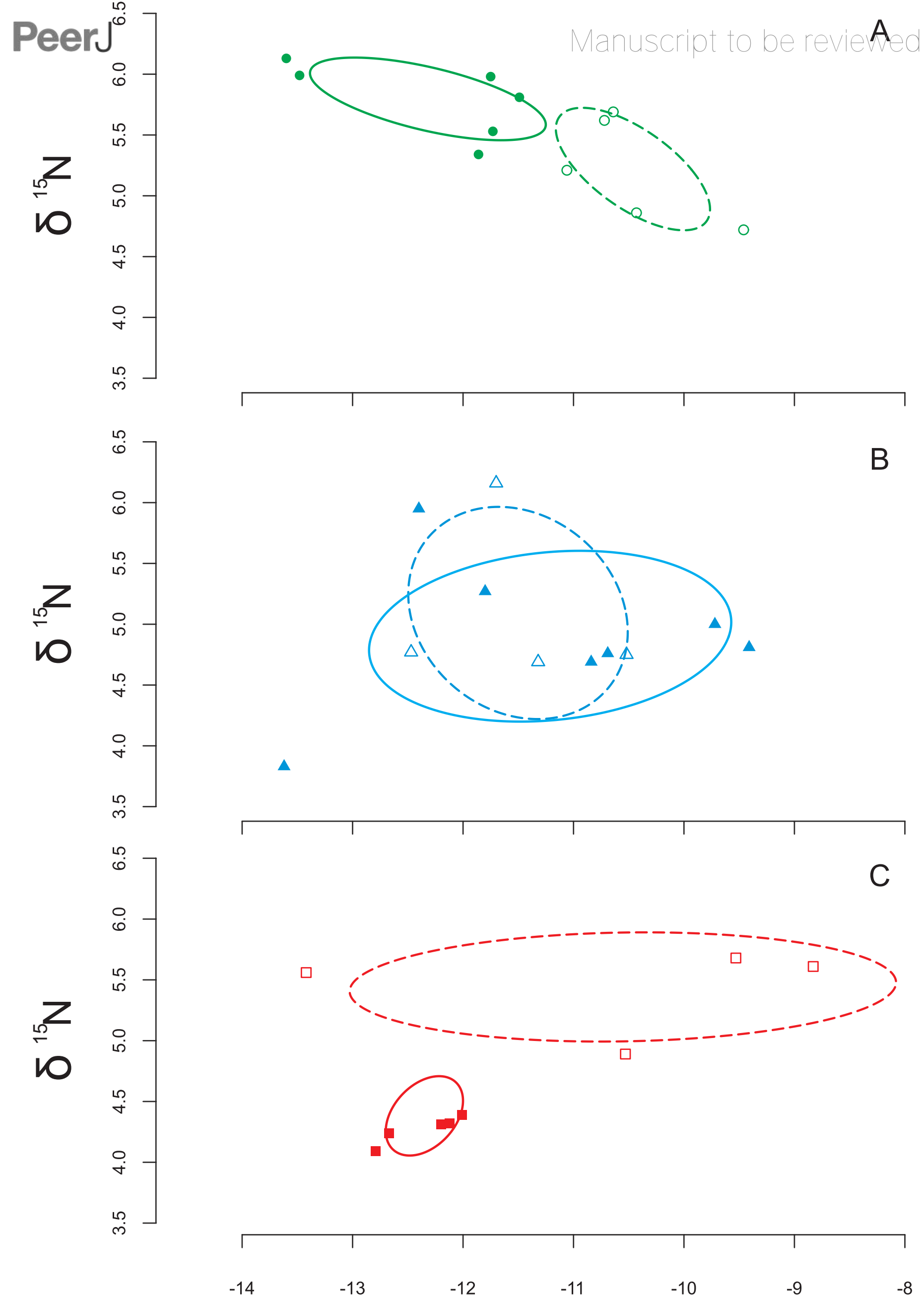

PeerJ reviewing PDF | (2019:03:35539:2:0:NEW 16 Jul 2019)

\section{$\delta{ }^{13} \mathrm{C}$}




\section{Table $\mathbf{1}$ (on next page)}

Algal biomass values

Mean \pm standard deviation values of algal biomass (grams dry weight $\cdot \mathrm{m}^{-2}$ ) at Mahahual, Xahuayxol and Xcalak. Genus considered for the mixing models analysis. Data below the grey line belongs to pelagic taxa. 
Table 1. Mean \pm standard deviation values of algal biomass (grams dry weight $\cdot \mathrm{m}^{-2}$ ) at Mahahual, Xahuayxol and Xcalak. Genus considered for the mixing models analysis. Data below the grey line belongs to pelagic taxa.

\begin{tabular}{|c|c|c|c|c|c|c|c|c|c|c|c|c|c|c|}
\hline \multicolumn{5}{|c|}{ Mahahual } & \multicolumn{5}{|c|}{ Xahuayxol } & \multicolumn{5}{|c|}{ Xcalak } \\
\hline Genus & WSE & & USE & & Genus & WSE & & USE & & Genus & $\begin{array}{l}\text { WS } \\
\text { E }\end{array}$ & & USE & \\
\hline Caulerpa & 39.49 & \pm 20.79 & 19.82 & \pm 6.48 & Caulerpa & 5.38 & \pm 0.93 & & & Caulerpa & 7.97 & \pm 3.51 & 7.75 & \pm 5.4 \\
\hline Dictyota & 19.92 & \pm 11.69 & 20.40 & \pm 5.41 & Dictyota & 6.61 & \pm 2.49 & 20.36 & \pm 5.96 & Codium & 3.01 & \pm 0.95 & & \\
\hline Halimeda & 133.50 & \pm 30.29 & 145.99 & \pm 36.21 & Halimeda & 118.07 & \pm 29.43 & 89.18 & \pm 9.998 & Dictyota & 21.99 & \pm 5.99 & 17.76 & \pm 2.34 \\
\hline Laurencia & 14.73 & \pm 22.15 & & & Laurencia & 8.49 & \pm 4.10 & & & Lobophora & 26.96 & \pm 4.30 & & \\
\hline Stypopodium & 95.41 & \pm 66.10 & & & Lobophora & & & 19.933 & \pm 11.50 & Padina & 12.62 & \pm 4.30 & & \\
\hline Turf & 24.69 & \pm 9.17 & 19.042 & \pm 6.045 & Penicillus & 12.88 & \pm 3.94 & & & Penicillus & 27.49 & \pm 3.51 & 26.23 & \pm 2.45 \\
\hline Udotea & 59.79 & \pm 45.74 & & & Sargassum & 14.26 & \pm 4.42 & & & Sargassum & 15.01 & \pm 4.30 & & \\
\hline & & & & & Stypopodium & 10.06 & \pm 12.13 & & & Turf & 12.00 & \pm 3.51 & 11.40 & \pm 4.21 \\
\hline & & & & & Turf & 5.886 & \pm 2.83 & 14.26 & \pm 7.84 & & & & & \\
\hline & & & & & Udotea & 39.13 & \pm 14.76 & 34.02 & \pm 16.54 & & & & & \\
\hline S. fluitans & & & 12.39 & \pm 8.33 & S. fluitans & & & 11.86 & \pm 2.75 & S. fluitans & & & 13.00 & \pm 6.99 \\
\hline S. natans & & & 4.92 & \pm 3.14 & S. natans & & & 7.07 & \pm 3.26 & S. natans & & & 10.03 & \pm 7.94 \\
\hline $\begin{array}{l}\text { Sargassum's } \\
\text { associated turf }\end{array}$ & & & 3.10 & \pm 1.21 & $\begin{array}{l}\text { Sargassum's } \\
\text { associated } \\
\text { turf }\end{array}$ & & & 3.23 & \pm 1.28 & $\begin{array}{l}\text { Sargassum's } \\
\text { associated } \\
\text { turf }\end{array}$ & & & 1.98 & \pm 1.29 \\
\hline
\end{tabular}

11 


\section{Table 2 (on next page)}

Values of $\delta^{13} \mathrm{C}$ and $\delta^{15} \mathrm{~N}$ of algal genus considered in the mixing model

Mean \pm standard deviation values of $\delta^{13} \mathrm{C}$ and $\delta^{15} \mathrm{~N}$ of algal genus considered in the mixing model analysis taken from Mahahual, Xahuayxol and Xcalak, the asterisks represent the sources under Sargassum effect. 
Table 2 Mean \pm standard deviation values of $\delta^{13} \mathrm{C}$ and $\delta^{15} \mathrm{~N}$ of algal genus considered in the mixing model analysis taken from Mahahual, Xahuayxol and Xcalak, the asterisks represent the sources under Sargassum effect.

\begin{tabular}{|c|c|c|c|c|c|c|c|c|c|c|c|c|c|c|c|c|c|}
\hline \multirow{3}{*}{$\frac{\text { Genus }}{\text { Caulerpa }}$} & \multicolumn{5}{|c|}{ Mahahual } & \multicolumn{7}{|c|}{ Xahuayxol } & \multicolumn{5}{|c|}{ Xcalak } \\
\hline & \multicolumn{3}{|c|}{$\delta^{13} \mathrm{C}$} & \multicolumn{2}{|r|}{$\delta^{15} \mathrm{~N}$} & \multirow{2}{*}{$\frac{\text { Genus }}{\text { Caulerpa }}$} & \multicolumn{3}{|c|}{$\delta^{13} \mathrm{C}$} & \multicolumn{2}{|r|}{$\delta^{15} \mathrm{~N}$} & \multirow{2}{*}{$\frac{\text { Genus }}{\text { Caulerpa }}$} & \multicolumn{3}{|c|}{$\delta^{13} \mathbf{C}$} & \multicolumn{2}{|c|}{$\delta^{15} \mathrm{~N}$} \\
\hline & -9.89 & \pm & 0.15 & 2.22 & \pm 0.01 & & -8.86 & \pm & 0.19 & 5.68 & \pm 0.01 & & -12.60 & \pm & 0.04 & 1.00 & \pm 0.10 \\
\hline Caulerpa* & -16.22 & \pm & 0.55 & 0.93 & \pm 0.08 & Dictyota & -15.71 & \pm & 0.90 & 2.29 & \pm 0.41 & Caulerpa* & -9.63 & \pm & 0.02 & 2.02 & \pm 0.08 \\
\hline Dictyota & -16.38 & \pm & 1.23 & 1.56 & \pm 1.37 & Dictyota* & -16.31 & \pm & 0.95 & 0.71 & \pm 0.02 & Codium & -12.17 & \pm & 0.07 & 1.25 & \pm 0.07 \\
\hline Dictyota* & -15.95 & \pm & 0.04 & 0.82 & \pm 0.04 & Halimeda* & -12.61 & \pm & 1.70 & 0.88 & \pm 0.01 & Dictyota & -15.47 & \pm & 0.68 & 0.67 & \pm 0.03 \\
\hline Halimeda & -7.01 & \pm & 1.25 & 0.29 & \pm 0.43 & Laurencia & -14.81 & \pm & 0.23 & 1.36 & \pm 0.71 & Dictyota* & -15.69 & \pm & 0.20 & 0.04 & \pm 0.06 \\
\hline Halimeda* & -8.39 & \pm & 0.69 & 0.68 & \pm 0.12 & Lobophora* & -10.49 & \pm & 1.35 & 0.33 & \pm 0.64 & Lobophora & -14.15 & \pm & 0.53 & 0.77 & \pm 0.33 \\
\hline Laurencia & -16.16 & \pm & 0.90 & 2.61 & \pm 1.41 & Penicillus & -11.51 & \pm & 8.28 & 1.84 & \pm 0.30 & Padina & -10.18 & \pm & 0.18 & 0.25 & \pm 0.19 \\
\hline Stypopodium & -11.33 & \pm & 0.52 & 0.67 & \pm 0.05 & Sargassum & -14.65 & \pm & 1.82 & 3.21 & \pm 0.23 & Penicillus & -14.50 & \pm & 0.08 & 0.06 & \pm 0.08 \\
\hline Turf & -13.44 & \pm & 0.00 & 3.03 & \pm 0.02 & Stypopodium & -16.80 & \pm & 1.40 & 1.47 & \pm 0.56 & Penicillus* & -9.75 & \pm & 0.14 & 1.98 & \pm 0.04 \\
\hline Turf* & -16.54 & \pm & 0.22 & -0.51 & \pm 0.02 & Turf & -16.43 & \pm & 1.32 & 1.84 & \pm 0.30 & Sargassum* & -14.76 & \pm & 0.87 & 0.37 & \pm 0.08 \\
\hline \multirow[t]{2}{*}{ Udotea } & -12.86 & \pm & 0.42 & 2.19 & \pm 0.03 & Turf* & -18.56 & \pm & 0.04 & -0.89 & \pm 0.11 & Turf & -17.44 & \pm & 0.48 & 4.59 & \pm 0.64 \\
\hline & & & & & & $\begin{array}{l}\text { Udotea } \\
\text { Udotea* }\end{array}$ & $\begin{array}{l}-11.62 \\
-12.65 \\
\end{array}$ & $\begin{array}{l} \pm \\
\pm\end{array}$ & $\begin{array}{l}1.34 \\
0.20 \\
\end{array}$ & $\begin{array}{l}2.42 \\
2.65 \\
\end{array}$ & $\begin{array}{l} \pm 1.12 \\
\pm 0.77 \\
\end{array}$ & Turf* & -21.98 & \pm & 0.10 & 0.41 & \pm 0.01 \\
\hline S. fluitans & -16.03 & \pm & 0.99 & -0.53 & \pm 0.26 & S. fluitans & -16.36 & \pm & 0.15 & -1.74 & \pm 0.38 & S. fluitans & -16.26 & \pm & 0.17 & -2.51 & \pm 0.52 \\
\hline $\begin{array}{l}\text { S. natans } \\
\text { Sargassum's }\end{array}$ & -17.44 & \pm & 0.71 & -1.59 & \pm 0.70 & $\begin{array}{l}\text { S. natans } \\
\text { Sargassum's }\end{array}$ & -16.82 & \pm & 0.73 & -1.49 & \pm 0.42 & $\begin{array}{l}\text { S. natans } \\
\text { Sargassum's }\end{array}$ & -17.28 & \pm & 0.81 & -1.62 & \pm 0.55 \\
\hline $\begin{array}{l}\text { associated } \\
\text { turf } \\
8 \\
9 \\
10 \\
11 \\
12 \\
13\end{array}$ & -18.29 & \pm & 0.51 & -1.13 & 0.05 & $\begin{array}{l}\text { associated } \\
\text { turf }\end{array}$ & -15.93 & \pm & 0.79 & -0.47 & 0.07 & $\begin{array}{l}\text { associated } \\
\text { turf }\end{array}$ & -16.27 & \pm & 0.63 & -0.96 & $\pm \quad 0.01$ \\
\hline
\end{tabular}




\section{Table 3 (on next page)}

Average percentage (\%) contribution of algal species to the diet of $D$. antillarum

Average percentage (\%) contribution of algal species to the diet of $D$. antillarum considering the effect of Sargassum: Without Sargassum effect (WSE) and Under Sargassum effect (USE) at Mahahual, Xahyayxol and Xcalak produced by the SIAR model using isotope values from algae. Minimum and maximum values for each algae are shown in parentheses. 
1

2

3

4

5

6

Table 3. Average percentage (\%) contribution of algal genus to the diet of the sea urchins D. antillarum considering the effect of Sargassum: without Sargassum effect (WSE) and under Sargassum effect (USE) at Mahahual, Xahyayxol and Xcalak produced by the SIAR model using isotope values from algae. Minimum and maximum values for each algae are shown in parentheses.

Mahahual

Genus

Caulerpa

Dictyota

Halimeda

Laurencia

Stypopodium

Turf

Udotea

S. fluitans

S. natans

Sargassum's associated turf

WSE

$19(1-37)$

$$
9(0-22)
$$$$
16(1-29)
$$

$12(0-25)$

$12(0-25)$

$17(0-34)$

15 (0-29)

USE

$14(0-31)$

$$
14(0-31)
$$

$31(17-44)$

-

11(0-26)

-

12(0-28)

$9(0-23)$

$9(0-22)$

Udotea

Laurencia

$11(0-21)$

Lobophora

Penicillus

$8(0-18)$

Sargassum

$12(0-23)$

Stypopodium

$11(0-21)$

$11(0-22)$

$12(0-23)$

28 (2-61)

$20(0-38)$

Penicillus

Turf

Sargassum

S. fluitans

S. natans

$6(0-17)$

Sargassum's associated turf $-\quad 6(0-17)$

S. natans

Sargassum's associated turf

$\begin{array}{lll}\text { S. fluitans } & - & 6(0-17) \\ \begin{array}{l}\text { S. natans } \\ \begin{array}{l}\text { Sargassum's } \\ \text { associated turf }\end{array}\end{array} & - & 6(0-17) \\ & & 8(0-21)\end{array}$

7

8 


\section{Table 4 (on next page)}

Trophic level of $D$. antillarum

Mean of Trophic level (TL) and standard deviation (STD) of D. antillarum without Sargassum effect (WSE) and under Sargassum effect (USE) at Mahahual, Xahuayxol and Xcalak. 
1

2

3

4

5

6

9

10

11

12

13

14

15

16

17

18

19

20

21

22

23

24

25

26

27

28

29

30

31

32

33

Table 4. Mean Trophic level (TL), and $\delta^{15} \mathrm{~N}$ and $\delta^{13} \mathrm{C} \pm$ standard deviation of D. antillarum without Sargassum effect (WSE) and under Sargassum effect (USE) at Mahahual, Xahuayxol and Xcalak.

\begin{tabular}{lllllll}
\hline \multicolumn{1}{c}{ Site } & TL WSE & TL USE & $\delta^{15} \mathbf{N}$ WSE & $\delta^{15}$ USE & $\delta^{13} \mathbf{C}$ WSE & $\delta^{13}$ USE \\
\hline Mahahual & $2.35 \pm 0.18$ & $3.08 \pm 0.13$ & $5.22 \pm 0.43$ & $5.8 \pm 0.3$ & $-10.46 \pm 0.6$ & $-12.32 \pm 0.95$ \\
Xahuayxol & $2.13 \pm 0.3$ & $2.49 \pm 0.27$ & $5.09 \pm 0.71$ & $4.9 \pm 0.24$ & $-11.5 \pm 0.81$ & $-11.21 \pm 1.48$ \\
Xcalak & $2.62 \pm 0.15$ & $2.45 \pm 0.12$ & $5.44 \pm 0.18$ & $4.38 \pm 0.29$ & $-10.58 \pm 2.01$ & $-12.02 \pm 0.89$
\end{tabular}




\section{Table 5 (on next page)}

Trophic niche breadth variations in face of Sargassum blooms

Trophic niche breadth of sea urchins without Sargassum effect (WSE) and under Sargassum effect (USE) at Mahahual, Xahuayxol and Xcalak calculated by SIBER analysis of muscle values. SEAc: corrected standard ellipse area. 
1

2

3

4 Table 5. Trophic niche breadth of sea urchins without Sargassum effect (WSE) and under Sargassum effect (USE)

5 at Mahahual, Xahuayxol and Xcalak calculated by SIBER analysis of muscle values. SEAc: corrected standard 6 ellipse area.

\begin{tabular}{lcccccc}
\hline \multicolumn{2}{c}{ Niche breadth } & \multicolumn{2}{c}{ Mahahual } & \multicolumn{2}{c}{ Xahuayxol } & \multicolumn{2}{c}{ Xcalak } \\
\hline & WSE & USE & WSE & USE & WSE & USE \\
SEA & 0.62 & 0.71 & 1.79 & 2.97 & 2.32 & 2.32 \\
SEAc & 0.83 & 0.89 & 2.68 & 3.57 & 3.48 & 0.14 \\
8 & & & & & &
\end{tabular}

